\title{
A vida e a morte dos guaiamuns: antropologia nos limites dos manguezais
}

Life and death of the blue land crabs: anthropology in the limits of the mangrove

Pedro Castelo Branco Silveira e Rafael Palermo Buti

\section{(2) OpenEdition}

12 Journals

Edição electrónica

URL: https://journals.openedition.org/aa/4945

DOI: $10.4000 /$ aa. 4945

ISSN: 2357-738X

Editora

Programa de Pós-Graduação em Antropologia Social (UnB)

\section{Edição impressa}

Paginação: 117-148

ISSN: 0102-4302

\section{Refêrencia eletrónica}

Pedro Castelo Branco Silveira e Rafael Palermo Buti, «A vida e a morte dos guaiamuns: antropologia nos limites dos manguezais», Anuário Antropológico [Online], v.45 n. 1 | 2020, posto online no dia 16 fevereiro 2020, consultado o 22 julho 2022. URL: http://journals.openedition.org/aa/4945 ; DOI: https://doi.org/10.4000/aa.4945

\section{(c) $)(9)$}

Creative Commons - Atribuição-NãoComercial-SemDerivações 4.0 Internacional - CC BY-NC-ND 4.0 https://creativecommons.org/licenses/by-nc-nd/4.0/ 


\title{
A vida e a morte dos guaiamuns: antropologia nos limites dos manguezais
}

\author{
Life and death of the blue land crabs: \\ anthropology in the limits of the mangrove \\ DOI: https://doi.org/10.4000/aa.4945
}

\author{
Pedro Castelo Branco Silveira • Fundaj-Brasil

\author{
Rafael Palermo Buti • Unilab - Brasil \\ Doutor e Mestre em Antropologia Social pela Universidade Federal de Santa Catarina (UFSC). É professor \\ e pesquisador na Universidade da Integração da Lusofonia Afro-brasileira (Unilab), em São Francisco do \\ Conde-BA.
}

O artigo explora as malhas relacionais da coexistência dos caranguejos conhecidos como guaiamuns (Cardisoma guanhumi) com os grupos humanos que os capturam em manguezais do litoral nordeste do Brasil. Apresenta as fricções na produção de paisagens de manguezal, ligadas a empreendimentos poluidores e aos controles e ordenamentos estatais. A análise posiciona a pesca de guaiamuns em uma diversidade de situações caracterizadas pela noção de limite: guaiamuns na transição entre o mangue e áreas adjacentes, entre a terra e a água, e vazando os limites de áreas protegidas; a vida dos pescadores nos limites da economia informal e da visibilidade política, tendo o mangue como segurança; a situação-limite das condições futuras de existência dos manguezais, dos guaiamuns e dos seus pescadores; e por fim, os limites do Estado em lidar com a diversidade dos modos de existência com criatividade na política ambiental. Articulando tais limites, indicamos necessidade de se imaginarem novas estratégias de assegurar o bem-viver de coletivos multiespécies que conformam os ambientes litorâneos, relacionando tal necessidade com a reivindicação da regulamentação do que as organizações de pescadores têm denominado de territórios pesqueiros.
This article explores the relational meshworks of co-existence of the blue land crabs (Cardisoma guanhumi) with fishermen in Northeastern Brazilian shore. It also presents frictions in the production of mangrove landscapes, including contaminating industrial and agroindustrial infrastructure as well as the influence of state control and planification in the lives of blue land crabs and its fishers. The analysis includes crab fisheries in a diversity of situations related to the notion of limit: crabs living in a transition between land and water, and spilling over the boundaries of protected areas; life of fishers in the limits of informal economy and political visibility, who have the mangrove as household safety; the limiting situation of the future of mangrove forests and of the existence of crabs and its fishers; and the limitations of the State in dealing with policies that join diversity of modes of existence and creativity in environmental policy-making. Articulating these limits, we indicate the need of imagining new strategies to assure the good living of multispecies collectives that shape the coastal environments, and we introduce the claim of fishers organizations for regularization of fisheries territories.

Multispecies studies. Mangrove. Fisheries territories. Blue land crab. Cardisoma guanhumi. 


\section{Introdução: antropologia, ambiente e limites}

O presente artigo explora as malhas relacionais da coexistência dos caranguejos conhecidos como guaiamuns (Cardisoma guanhumi) com os grupos humanos que os capturam como atividade econômica e alimentar, em manguezais do litoral nordeste do Brasil. Ele também analisa o rebatimento das práticas e políticas de gestão e ordenamento do Estado ligados aos territórios habitados por pescadores e por guaiamuns. Para isso, explora também as diversas formas como a ideia de limite pode ser acionada para lidar com as situações etnográficas estudadas.

Nossa argumentação dialoga, por um lado, com os debates em antropologia que lidam com a relação natureza-cultura (Latour, 1994; Ingold, 2000; Viveiros de Castro, 2002; De la Cadena, 2015; Escobar, 2015) e, por outro, com as discussões sobre as relações entre os direitos dos chamados povos tradicionais e as perspectivas ambientalistas (Carneiro da Cunha; Almeida, 2000; Little, 2002). Assim, partimos de uma perspectiva ecológica das relações humanas que é também uma perspectiva social das relações ecológicas, no sentido de pensar os mundos humanos como mundos de relações vividas, de que os humanos fazem parte.

Uma categoria importante aqui é a paisagem, pensada como uma malha de relações vitais produzidas pelo movimento de seres e de materiais (Ingold, 2015). Nessa malha podem ser identificadas relações multiespécies passíveis de serem estudadas, inclusive da perspectiva da precarização das possibilidades de tais relações por processos de destruição e contaminação típicos do chamado Antropoceno (Tsing, 2019).

Nosso esforço teórico-metodológico neste artigo é, por um lado, o de experimentar uma antropologia ecológica a partir do engajamento nas paisagens dos manguezais, guiados pela experiência dos pescadores de guaiamum e, por outro lado, relacionar, em colaboração com os pescadores, estas perspectivas experienciadas em termos de ecologia política, ou seja, no sentido de refletir sobre a continuidade no tempo da existência das paisagens dos manguezais, dos modos de existir dos guaiamuns e dos pescadores.

A ideia de limite aqui desenvolvida dialoga com o conceito de fricção ou atrito (friction) proposto por Anna Tsing (2004; 2012). Para ela, não é possível compreender os fenômenos do capitalismo global senão a partir de processos que conectam seu modo de operação e as particularidades locais. Em outras palavras, os fenômenos globais não ocorrem em uma esfera abstrata, mas sim em lugares onde outras coisas também acontecem. Por isso, para se compreenderem os processos globais, é essencial entender a fricção envolvida em suas diversas formas de concretização empírica. A fricção inclui não apenas os conflitos, mas também "outros tipos de interações baseadas na diferença, como alianças, empréstimos, fusões, traduções e acomodações” (Tsing, 2012).

Essa autora tem ainda desenvolvido sua argumentação no sentido de abordar tais conexões a partir de uma perspectiva da vida multiespécies (Tsing 2015a; Van Dooren et al., 2016), em que os engajamentos humanos no mundo se dão a partir de relações com outras formas de vida. Tsing mostra, por exemplo, que se a história da expansão colonial dos povos europeus pelo resto do planeta for contada 
a partir das relações com os fungos, desafiam-se ideias consolidadas de supremacia humana como a noção de domesticação (Tsing, 2015a). Mostra também que paisagens onde espécies foram extintas trazem nas relações presentes os ecos de sua ausência; e que certas transformações provocam a proliferação descontrolada e não planejada (feral) de certas espécies, numa completa transformação da paisagem (Tsing et al., 2017). O reconhecimento da agência de não-humanos na configuração das paisagens, portanto, abre as portas para tomarmos "as paisagens multiespécies como protagonistas de histórias do mundo” (Tsing, 2015a).

Defendemos, assim, a impossibilidade de uma narrativa genérica sobre ecologia política do guaiamum. É preciso contar histórias sobre como processos globais afetam, de maneira relativamente incompleta, a malha de relações que compõem as paisagens onde ocorrem guaiamuns e, ao produzirem interconexões locais, dão espaço a linhas de fuga. Por isso a importância de conhecermos e descrevermos, localmente, "o engajamento e o encontro através dos quais trajetórias globais tomam forma” (Tsing, 2012). Tais engajamentos e encontros são relações múltiplas de socialidade de humanos e não-humanos, conformando paisagens e relações multiespécies (Tsing, 2013).

O objetivo do artigo, portanto, é produzir uma narrativa sobre relações e paisagens multiespécies tomando como referência duas situações etnográficas envolvendo a pesca de guaiamuns no nordeste brasileiro. $\mathrm{O}$ texto traz reflexões a partir de um projeto de pesquisa coletivo do qual os dois autores participam, que tem como objetivo estudar a ecologia política da pesca de três espécies de caranguejos (guaiamum, caranguejo-uçá e aratu) em cinco paisagens estuarinas do litoral Nordeste do Brasil ${ }^{1}$. Procurando nos engajar em uma "ecologia política não-essencialista" (Robbins, 2004), nos propomos a investigar que tipo de giro de ponto de vista obtemos ao estudar questões socioambientais a partir de uma perspectiva antropológica que pensa a produção multiespécies das paisagens (Tsing, 2015b; Cardoso, 2017).

Cada paisagem pesquisada constitui, assim, uma malha socioecológica diversa e dinâmica, produtora de mundos relacionais habitados, também, pelos pescadores. Compreender esses mundos implica deixar-se guiar pelos pescadores na educação de nossa atenção (Ingold, 2010; 2016), e assim perceber, acompanhando as atividades de pesca ao longo dos manguezais, as formas e os dilemas de habitá-lo.

O presente trabalho é também resultado da participação dos autores nos debates públicos e atividades coletivas relacionadas a pesca e seus territórios, incluindo os referentes ao chamado ordenamento da pesca do guaiamum face à ameaça de proibição da atividade por motivos de conservação ambiental. As histórias aqui narradas $^{3}$ referem-se a duas paisagens: os manguezais do estuário do Rio Goiana, na divisa litorânea entre os estados de Pernambuco e Paraíba, onde existe desde 2007 a Reserva Extrativista Acaú-Goiana; e os manguezais do município de São Francisco do Conde, às margens da Baía de Todos os Santos no estado da Bahia, onde uma comunidade quilombola reivindica reconhecimento territorial desde 2008.
1 O projeto chama-se "Ecologia política da pesca de crustáceos em manguezais do Nordeste brasileiro" (2017-2019), realizado e financiado pela Fundação Joaquim Nabuco sob a coordenação do pesquisador Pedro Silveira. As áreas de pesquisa são as duas mencionadas neste artigo, mais os manguezais do Delta do Parnaíba (MA) $\mathrm{PI})$, de Passo do Camaragibe $(A L)$ e de Canavieiras (BA). 2 Tim Ingold usa a ideia de educação da atenção, apropriada do psicólogo James Gibson (1979), defendendo que o aprendizado não se dá por transmissão de representações mentais, mas pelo engajamento nas práticas. Uma pessoa ensina algo a outra fazendo junto, e/ ou mostrando como se faz. Segundo Ingold (2010, p. 21), "o papel do tutor é criar situações nas quais o iniciante é instruído a cuidar especialmente deste ou daquele aspecto do que pode ser visto, tocado ou ouvido, para poder assim 'pegar o jeito' da coisa". Em outro artigo, esse autor defende que o trabalho de campo do antropólogo consiste basicamente em tornar-se aprendiz e educar sua atenção em campo, orientado por seus interlocutores. "Se o método da antropologia envolve um trabalho prático com pessoas e materiais", diz Ingold, "então sua disciplina está no engajamento observacional e educação perceptual que permite ao praticante acompanhare responder àquilo que acontece" (Ingold, 2016, p. 409).

3 O trabalho de campo no Rio Goiana foi realizado por Pedro Silveira, enquanto em São Francisco do Conde foi feito por Rafael Buti com colaboração de Pedro Silveira. 


\section{Os modos de existência dos guaiamuns}

Os guaiamuns, também chamados de goiamuns ou gaiamuns, são caranguejos vistosos, de coloração azulada, cuja largura do casco pode atingir tamanhos até 10 ou 12 centímetros. A espécie foi descrita cientificamente em 1825 pelo naturalista francês Pierre André Latreille, que o batizou com o nome de Cardisoma guanhumi. São encontrados ao longo da Costa Atlântica e Caribe na América tropical e subtropical, sendo comuns no litoral Sudeste e Nordeste do Brasil, tendo seu limite sul de ocorrência no estado de Santa Catarina (Oliveira Neto et al., 2014). A distribuição ao norte ocorre ao longo da costa da Venezuela, Colômbia, América Central, chegando aos EUA em Porto Rico até a Flórida. Trata-se de animais de valor alimentar e comercial, que são alvo tradicional de captura pelos moradores das áreas litorâneas, ao longo de sua distribuição. São conhecidas outras seis espécies de caranguejos semelhantes ao guaiamum, classificadas sob o mesmo gênero Cardisoma, em outras áreas dos trópicos (Burggren e McMahon, 1988).

Os guaiamuns habitam um tipo de ambiente bastante específico. Vivem em áreas de matas alagáveis, restingas e outras fisionomias de vegetação que circundam os manguezais. Os manguezais são ambientes de transição entre a água doce e o mar, caracterizados pela variação diária de salinidade da água dos rios, por influência das marés. Os guaiamuns não vivem dentro dos manguezais, mas na transição entre estes e as vegetações de terra firme circundante, que também podem ser entendidas como vegetações terrestres de transição entre o mar e a floresta. Assim, podemos dizer que os guaiamuns habitam ambientes essencialmente limítrofes das categorias de classificação de paisagens de que dispomos. Desse modo, não são exatamente animais terrestres nem aquáticos, não vivem exatamente no mangue ou na floresta. Habitam o que os biólogos chamam de ecótono, ou seja, um ambiente de transição entre duas unidades de paisagem. Nesse sentido, habitam os limites de sua paisagem.

A vida em tal tipo de ambiente está ligada a um modo de existir bastante peculiar, que implica uma dependência da proximidade da água estuarina, doce ou com certo grau de salinidade, do terreno moderadamente úmido, com água a poucos metros da superfície, e da existência de alimento produzido pela vegetação terrestre circundante a suas habitações.

Os guaiamuns vivem solitários em buracos que cavam no solo. Tanto os pescadores que acompanhamos quanto a literatura científica (Sample e Albrecht, 2016) descrevem esses buracos como formados por um túnel de comprimento variável que termina em uma câmara que alcança a água localizada em uma profundidade de aproximadamente dois metros. Dentro de seus buracos, os guaiamuns estão protegidos de seus predadores. Há outros predadores dos guaiamuns, além dos humanos, como os guaxelos (Procyon cancrivorus), alguns gaviões e raposas, dentre outros animais carnívoros que habitam o mesmo tipo de ambiente.

Os guaiamuns saem de sua morada principalmente para buscar alimento, para defecar à entrada do buraco e no período reprodutivo, quando migram para procurar parceiros ou parceiras sexuais. A literatura científica indica que seu período de atividade fora dos buracos é principalmente no nascer do dia e no pôr-do-sol, 
mas a atividade de captura do guaiamum se dá desde o nascer do dia até o fim da tarde. Em certas ocasiões, as armadilhas, que descreveremos à frente, são deixadas no período da noite para serem recolhidas no dia seguinte, o que indica que os animais procuram as iscas em horários variados.

Sua alimentação é composta principalmente por frutos e folhas da vegetação circundante ao seu buraco, mas é comum dizer-se que o guaiamum pode eventualmente se alimentar de animais em decomposição ou mesmo de fezes (Firmo et al., 2012). Em nossa experiência de campo, os interlocutores nos indicaram tal generalidade de dieta, e também o grande apreço dos guaiamuns pela polpa do dendê (Elaeis guineensis), espécie de palmeira introduzida no Brasil a partir da África, que ocorre espontaneamente no Nordeste brasileiro (Watkins, 2015; Cardoso, 2016), sendo muito comum nas matas alagáveis que circundam os manguezais do litoral nordestino.

Muitas vezes, após capturados, os guaiamuns são confinados em cercados, gaiolas ou tanques, conhecidos como caritós (em Pernambuco) ou viveiros (no Recôncavo da Bahia). Podem viver até meses nesses cativeiros, alimentados com dendê, verduras, cuscuz de milho ou outros alimentos de origem vegetal. Nessas condições, os animais vivem agrupados, desprovidos de sua proteção nos buracos, em condição completamente diferente da vida em seu ambiente 4 .

Como os guaiamuns têm uma alimentação variada e predominantemente vegetal, eles sobrevivem relativamente bem em áreas agrícolas, se suas condições básicas de vida são mantidas nesses ambientes. Assim, é comum encontrar esses caranguejos habitando roças localizadas nos arredores dos manguezais, e mesmo áreas de monocultura de cana-de-açúcar. A prática de queimada, entretanto, é extremamente nociva aos guaiamuns, e ainda mais nocivo é o efeito dos agroquímicos. Por conta desta relativa compatibilidade do modo de existência desses animais com certos ambientes agrícolas estabelecidos sobre suas áreas de vida, em vários locais os guaiamuns são parte da dieta dos agricultores e em outros são considerados pragas agrícolas, como ocorre em Porto Rico e na Flórida (Hill, 2001).

O modo de habitar do guaiamum também contribui para produzir paisagens. Um líder comunitário do Sul da Bahia contou-nos que os fazendeiros de camarões de sua região, que estabelecem os tanques de criação sobre as áreas de vida dos guaiamuns, pagam funcionários para aplicar agroquímicos nas imediações dos tanques com o específico objetivo de matar os guaiamuns, pois esses, ao construírem seus buracos, muitas vezes terminam por criar vazamentos dos tanques de camarões para dentro dos mangues.

É parte do modo de existência dos guaiamuns uma variação de suas atividades ao longo do ano, relacionadas ao desenvolvimento corporal e à reprodução. Essa sazonalidade, conforme acompanhamos, ocorre da seguinte forma nas áreas estudadas: nos meses de outubro a dezembro, os guaiamuns, machos e fêmeas, começam a ficar ativos, saindo com frequência de suas tocas para se alimentar. Alguns ainda estão com as carapaças novas, recém-trocadas, fruto de seu processo de crescimento, mas já endurecidas. Nesse período, os guaiamuns passam a ficar mais visíveis ao pescadores, que encontram os buracos destapados, com
4 Manter os guaiamuns em condições de cativeiro após a captura tem relação, por um lado, a situações de venda direta ao consumidor, seja pelo próprio pescador, pelo atravessador ou em um restaurante. Por outro lado, é uma prática que induz a uma modificação do sabor do animal pela ingestão controlada dos alimentos oferecidos, tornando-o mais gordo e com gosto diferenciado do que adquire na alimentação em seu ambiente. Vale destacar que uma importante característica do consumo do guaiamum é que ele precisa chegar vivo ao consumidor, sendo morto apenas no momento do preparo. É servido inteiro, tendo seu exoesqueleto quebrado e todas os músculos e órgãos aproveitados para consumo, retiradas apenas as fezes. Assim, a alimentação recente do animal faz diferença importante no sabor que terá no consumo. 
rastros e fezes em suas entradas. A quantidade de guaiamuns adultos ativos vai aumentando com a chegada do verão, sendo a partir daí o melhor período para a captura, e também o período em que encontramos uma maior quantidade de pescadores em atividade.

As atividades de reprodução se dão em dias específicos nos meses do verão, que em geral coincidem com a lua cheia, mas eventualmente podem coincidir também com a lua nova. Nesses dias, conhecidos como andada $a^{5}$ termo que foi incorporado ao vocabulário da legislação, os guaiamuns saem dos buracos e passam a circular na paisagem, podendo cruzar áreas de mangue, áreas urbanas e estradas. Nesse processo, encontram parceiros e parceiras para copular e podem ocupar novos buracos. Durante o verão, fora dos dias de andada, os guaiamuns seguem em atividade de forrageamento na vegetação e vida interna aos seus buracos.

Em um período de três ou quatro dias no final do verão ocorre um fenômeno que alguns pescadores chamam de andada das fêmeas, em que estas, com o ventre cheio de ovos (chamadas patachocas, na Bahia), vão desovar nas margens dos riachos dos manguezais. A partir desse período, os guaiamuns adultos começam a passar por uma redução de suas atividades externas. Parte dos animais passa a acumular alimentos dentro do buraco e tapá-lo com terra, ficando lá dentro por longo período. Esse fenômeno os pescadores de Goiana chamam matumbar-se, e os do Recôncavo Baiano chamam motumbar-se. Os guaiamuns não ficam matumbados todos de uma vez, havendo sempre uma parte da população com os buracos destapados, o que permite a existência de atividade de uma parte dos pescadores ao longo de quase todo o ano. Nos meses de junho, julho e agosto, no inverno chuvoso do litoral nordestino, a maior parte dos guaiamuns está matumbado. Dentro do buraco, os animais procedem a seus processos de crescimento, livrando-se de seu exoesqueleto (casco) e ganhando um novo, maior, que demora um certo tempo para endurecer. Os pescadores que acompanhamos acreditam que o guaiamum enquanto se matumba, não está todo o tempo no processo de troca de casco, pois descrevem que é comum os animais saírem da matumba e se matumbarem novamente ao longo do inverno.

Conhecer os sinais das mudanças nos ciclo de vida dos guaiamuns adultos é essencial para os pescadores. Já o ciclo dos guaiamuns juvenis tem menos atenção de sua parte. Os caranguejos jovens são encontrados na área dos adultos, reportados em maior quantidade nos limites do mangue. Alguns dos pescadores que acompanhamos inferem que os guaiamuns juvenis, até uma certa fase de suas vidas, trocam de casco várias vezes no ano, e só a partir de um certo tamanho passam a fazer apenas uma troca.

Há um estranhamento dos pescadores que interagiram com pesquisadores biólogos, quando ouvem destes que os filhotes dos guaiamuns são levados do rio até o mar, onde se desenvolvem e retornam até o mangue novamente. Os pescadores avaliam, de forma geral, que os filhotes dos guaiamuns nascem na própria margem dos mangues e por ali ficam em seu processo de crescimento. O conhecimento científico disponível (ver, por exemplo, Weis, 2012) indica que os guaiamuns, assim como todos os tipos de caranguejos, tem uma fase larval
5 Na Bahia costuma-se dizer que as andadas são o carnaval e a brincadeira dos guaiamuns e caranguejos, por coincidirem com as datas do festejo humano. 
microscópica, chamada zoea. Essas larvas vivem como plâncton na coluna d'água, e em seu desenvolvimento se transformam em outro tipo de larva, batizada de megalopa, com formato já semelhante a um minúsculo caranguejo. No caso dos guaiamuns, estuda-se que um imenso número de larvas eclode dos ovos e é carreado ao mar, desenvolvendo-se na zona costeira. Após o desenvolvimento larval, aportam via movimento das marés na lama dos manguezais, podendo chegar ao mesmo estuário onde nasceram ou colonizar um novo estuário. Só então os animais juvenis se movimentam até a vegetação limítrofe dos manguezais para iniciar sua vida adulta (Burggren e McMahon, 1988).

Tomando por base a existência desta fase do ciclo de vida dos guaiamuns, identificada pelos biólogos, mas oculta da experiência sensível dos pescadores, ampliamos a compreensão da condição limítrofe que identificamos no modo de existência dos guaiamuns. Se na vida adulta habitam terrenos úmidos de vegetação terrestre, em uma relativa independência dos ambientes aquáticos, sua sobrevivência enquanto espécie está totalmente ligada à dinâmica aquática dos estuários para o desenvolvimento larval. Assim, os guaiamuns adultos habitam ambientes periféricos ao manguezal em si, mas são animais constituintes da paisagem estuarina do ecossistema manguezal, sendo sua existência um indicativo dos problemas envolvidos na separação entre o manguezal e a vegetação terrestre do seu entorno. Tal separação coloca as áreas de vida do guaiamum, que do ponto de vista do ciclo do animal são contínuas e contíguas, em esquemas classificatórios de organização e gestão da paisagem que fragmentam sua possibilidade de conservação, como discutiremos à frente. É válido mencionar que as áreas de vida dos guaiamuns adultos são ambientes que não recebem nem a proteção legal destinada aos manguezais, nem a proteção da legislação específica da Mata Atlântica ${ }^{6}$.

Para encerrar esta seção, vale uma nota para o uso que fazemos aqui do verbo pescar e do substantivo pescador para a atividade que estudamos. Como veremos a seguir, o modo de capturar os guaiamuns com armadilhas, percorrendo-se trilhas na vegetação terrestre, pouco nos remete a uma atividade de pesca, podendo eventualmente ser até entendido como um tipo de atividade de caça (o que também soaria estranho, em se tratando de uma espécie de crustáceo, que em geral são entendidos como seres do universo da pesca). As pessoas que capturam guaiamuns como atividade profissional, pelo menos no Brasil, costumam habitar as localidades pesqueiras do litoral, definindo-se como pescadores. Se o termo para a captura do guaiamum muitas vezes pode ser outro do que pescar, como tirar ou pegar, existe uma identificação sociológica e identitária dos trabalhadores do guaiamum como parte das comunidades pesqueiras litorâneas. Assim, os gaiamunzeiros são identificados neste artigo como pescadores. Esta condição por vezes ambígua da categorização nos é produtiva, pois evidencia mais um aspecto de "situação-limite" da vida e da morte dos guaiamuns e daqueles humanos que seguem seus sinais para viver.
6 Apesar das áreas chamadas de apicuns e outras periféricas aos mangues serem descritas nas recomendações de cientistas como áreas que fazem parte do ecossistema manguezal, e que este faz parte do chamado domínio da Mata Atlântica (Lima e Capobianco, 1997), a pressão pela instalação de empreendimentos e pela urbanização das áreas litorâneas fez com que a definição legal de manguezal incorporasse apenas uma versão reducionista do conceito, excluindo a área de vida dos guaiamuns. 


\section{Perambulando pelas paisagens dos guaiamuns do Rio Goiana (PE/PB)}

Jorge $^{7}$ aprendeu a pegar guaiamuns desde criança, quando morava na Ilha do Catucá. Essa ilha é uma das muitas que existem em meio aos manguezais que acompanham o rio Goiana desde sua foz até o fim da área de influência das marés, quase na altura em que a rodovia BR-101 cruza a sede do município de Goiana, no Litoral Norte de Pernambuco. O rio Goiana divide os estados de Pernambuco e Paraíba, na altura do litoral. Na faixa dos quarenta e poucos anos, Jorge vive hoje na cidade, numa pequena casa às margens desse rio, no bairro de Baldo do Rio, área urbana de Goiana. A vizinhança é formada em grande parte por pescadores artesanais que capturam peixes estuarinos e crustáceos nos manguezais.
7 Foram adotados nomes fictícios para preservar as identidades dos pescadores. 8 Aqui usamos o singular por se tratar da experiência de campo de um dos autores do artigo.

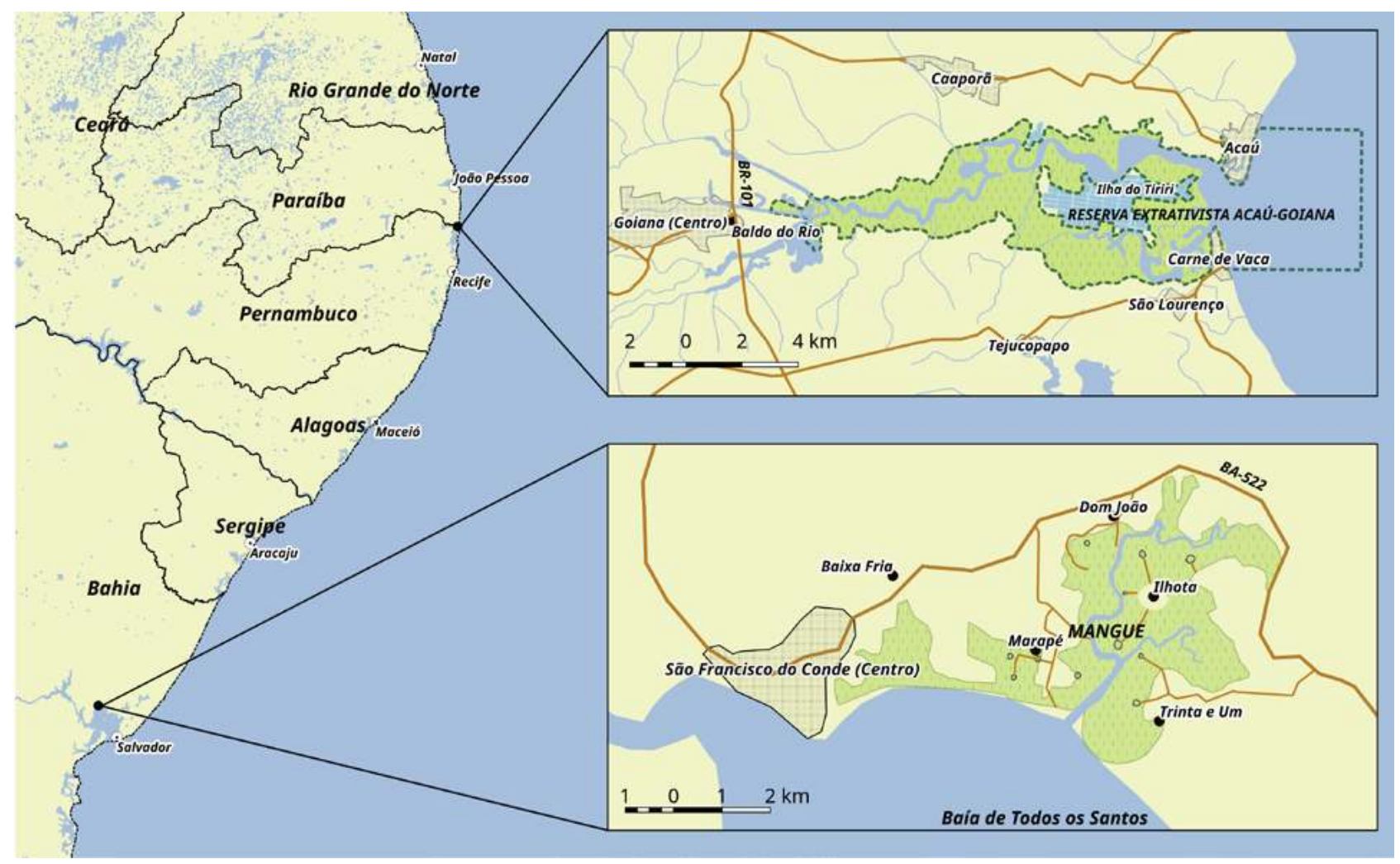

Acompanhei ${ }^{8}$ por duas vezes um dia de trabalho de Jorge, saindo muito cedo de Baldo do Rio em uma canoa provida de um motor de rabeta, com a qual nos deslocávamos rio abaixo até um porto conhecido. Numa das vezes fomos sozinhos; na segunda demos carona para dois rapazes na faixa dos 20 anos, parentes da esposa de Jorge e aos quais ele estava incentivando a trabalhar no guaiamum, segundo ele, como forma de ganhar a vida honestamente. Nessa ocasião, deixamos os rapazes de um dos lados do rio e paramos a canoa no lado oposto. Nas duas ocasiões, o local de parada foi o mesmo, e é uma das áreas onde Jorge costuma trabalhar, mas não a única.

Para chegar até lá, o caminho não tem muitos segredos. O rio Goiana, logo abaixo de Baldo do Rio, é uma paisagem reveladora dos efeitos da economia agroindustrial da Zona da Mata Pernambucana sobre as áreas estuarinas. Um outro pescador havia me contado, dias antes da primeira saída, que o rio que passa em Baldo vem de um braço morto mais acima, no próprio município de Goiana,
Figura 1: mapa das áreas de estudo, destacando as áreas de manguezal do estuário do Rio Goiana (PE/PB) e de São Francisco do Conde (BA). No estuário do Rio Goiana percebemos as povoações pesqueiras, os limites da Resex Acaú Goiana e a área de carcinicultura na Ilha de Tiriri. Em São Francisco do Conde evidencia-se o quilombo Porto Dom João e as áreas de manguezal entrecortadas por poços de petróleo desativados (círculos) e aterros que formam caminhos no manguezal, hoje utilizados apenas pelos gaiamunzeiros e caranguejeiros. Mapa elaborado por Allan Monteiro para este artigo. 
próximo a uma indústria de papel e celulose, mas que antigamente essa era a calha principal dele, vinda do interior, que foi desviada. Nas bordas do centro urbano, avistam-se canaviais por todos os lados. Segundo esse pescador, os proprietários de uma das usinas de cana foram responsáveis pela mudança do canal principal para mais alguns quilômetros à frente, num outro canal também retificado. Há ainda um terceiro canal retificado, também cercado de canaviais, alguns quilômetros antes de se chegar ao centro urbano de Goiana, vindo de Recife. Toda essa área, modificada e ocupada principalmente por cana, era área de ocorrência farta de guaiamuns no passado, e os animais ainda a habitam em menor densidade.

Esses três canais se encontram mais à frente com um outro rio, onde começam as áreas ainda hoje ocupadas por manguezais,. De dentro da canoa de Jorge, avistamos os canaviais, que algumas vezes se derramam quase para dentro do rio, e em outros trechos são disfarçados por uma rala vegetação em que se destacam as aningas (Montrichardia arborescens), capins e arbustos de um leguminosa conhecida como espinheiro. A canoa vai deslizando sobre a água e, misturado ao ronco do motor, Jorge me dá referências sobre a paisagem nas margens do rio. Mostra-me que um dos canais (camboas) que vemos foi aberto por máquina pela usina, outro foi fechado. A hidrografia da região é variável não só pelas reacomodações dos canais por efeitos não humanos, mas também por intervenções dos usineiros, visando ao aproveitamento do terreno adjacente para o plantio de cana.

Nesse caminho passamos também por dois ou três portos com canoas atracadas. Jorge me explica que são de moradores do centro urbano ou ex-trabalhadores das usinas que têm pequenos sítios em áreas que se espremem entre o canavial e o rio. Muitos desses sitiantes também pescam guaiamuns como atividade complementar, ou então permitem que os pescadores capturem os guaiamuns em seus roçados. Os guaiamuns, ele diz, podem viver no meio dos roçados, gostam de comer macaxeira e outros cultivos. Também vivem nas áreas de canavial próximas ao rio, mas quando a usina queima o canavial, os guaiamuns fogem correndo para dentro do rio. Nessas ocasiões, os animais podem ser capturados pelos pescadores, ao contrário das ocasiões em que a usina espalha veneno nas plantações, e ocorre uma grande mortalidade de guaiamuns e outros animais. "Aqui onde tem cana era tudo mato, era tudo mangue", me diz, afirmando também que o guaiamum "vive no mato, não gosta de viver no limpo".

As ratoeiras (Figura 2) são o apetrecho utilizado em vários locais do Brasil para pescar o guaiamum. São armadilhas construídas pelos próprios pescadores com materiais facilmente disponíveis em seu ambiente, incluindo uma estrutura cilíndrica que pode ser feita com garrafas PET, canos de PVC, embalagens plásticas diversas, latas de óleo ou de leite. Numa extremidade dessa estrutura prende-se uma tampa quadrada de madeira ou plástico, acoplada a um cabo, em geral de madeira. A tampa se liga ao cilindro por uma tira de borracha de pneu (ou liga). No fundo do cilindro é atravessado um arame onde se enfia uma isca para o guaiamum, que no caso de Jorge eram pequenos toletes de cana-de-açúcar. Podem ser usados também frutas cítricas, cebola, abacaxi ou outros alimentos de cheiro forte e atrativos aos caranguejos. Esse arame se prende, dentro da armadilha, à tira 
de borracha. Quando a isca é colocada e a ratoeira é armada, a tampa fica presa numa posição em que deixa aberta a entrada do cilindro. Essa abertura é disposta na entrada da toca do guaiamum, de modo que quando o animal sai da toca, ele entra na armadilha e tenta puxar a isca. $\mathrm{O}$ arame solta então a tira de borracha e provoca o fechamento da ratoeira, aprisionando o guaiamum.

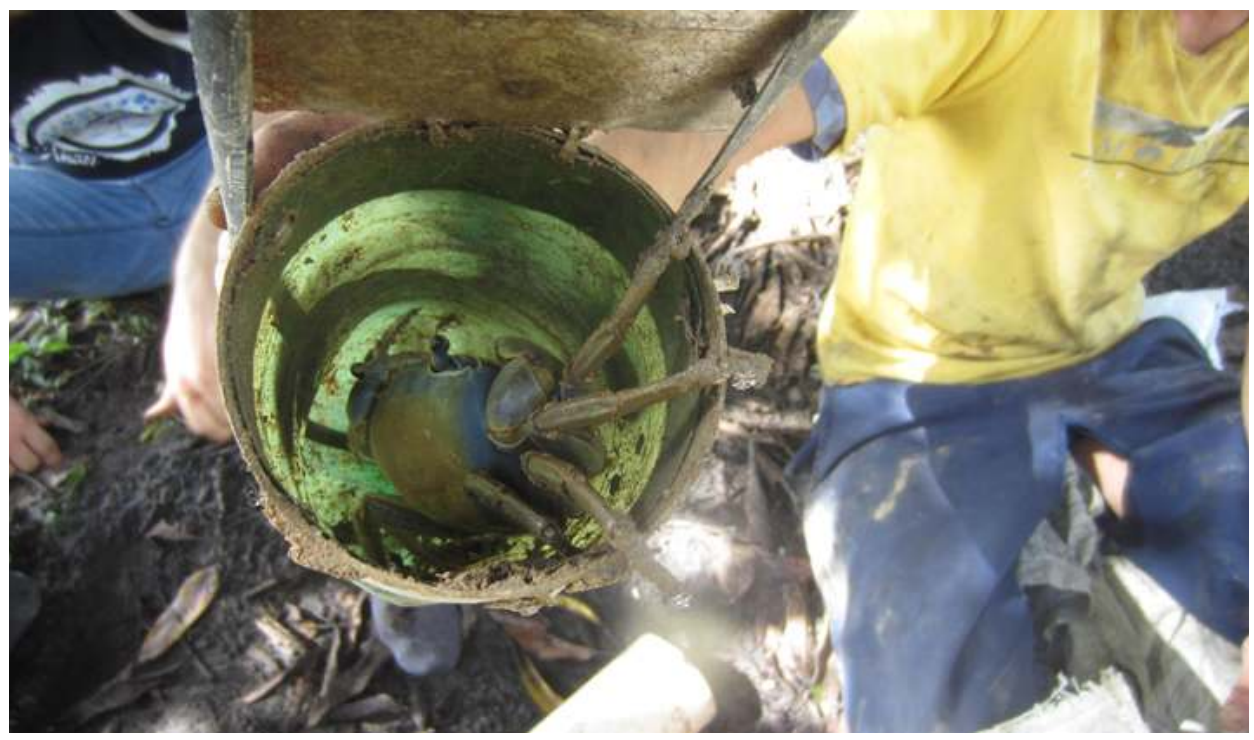

O porto onde paramos dá em uma vegetação de capins e arbustos. Jorge havia instalado as ratoeiras no dia anterior, vinha recolhê-las no dia em que o acompanhei e sabia exatamente onde elas estavam. Mesmo sendo na área de capim, as ratoeiras estavam colocadas em locais protegidos por vegetação. No caminho para a primeira ratoeira, Jorge vai me mostrando algumas tocas de guaiamum e dando uma estimativa se o animal daquela toca era grande ou pequeno. Me mostra também os rastros de bois e de capivaras que passaram pelo local. Os bois, diz ele, pisoteiam as ratoeiras; já as capivaras, deixam-nas em paz. Mais à frente me mostra rastros dos guaxelos, que são comedores de caranguejos e costumam levar para longe as ratoeiras para roubar os guaiamuns de dentro delas.

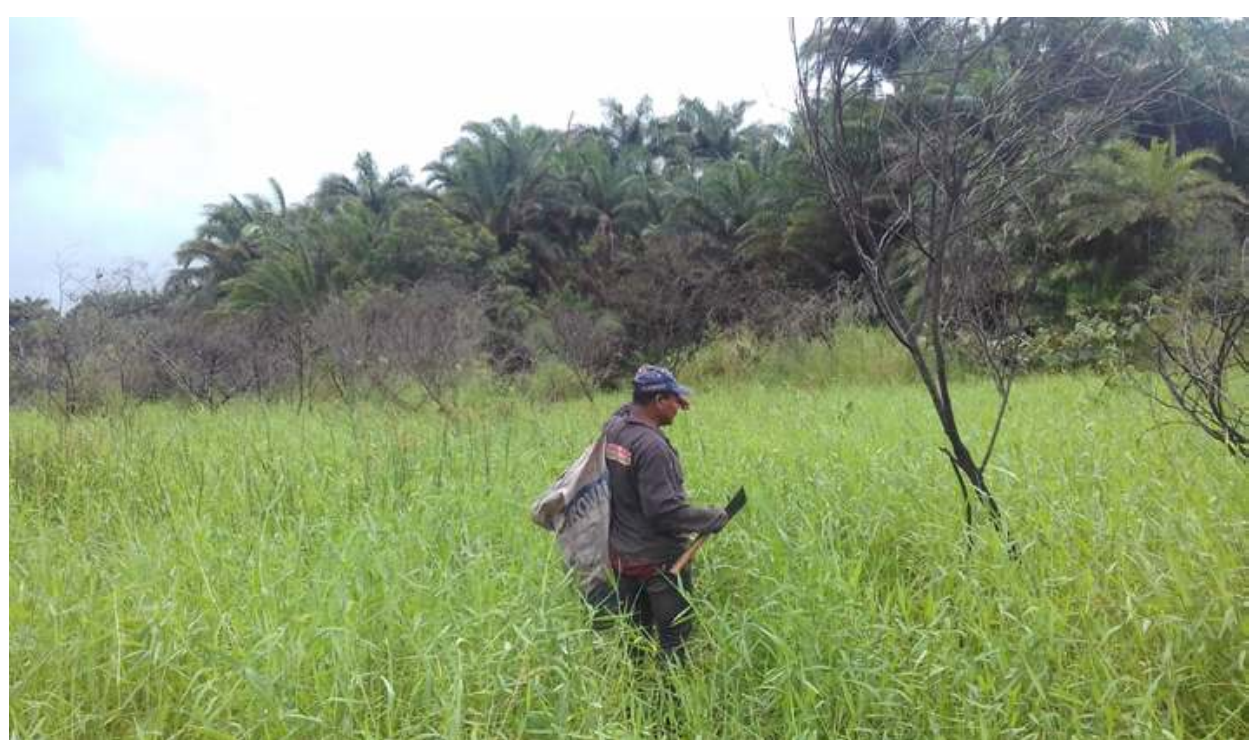

Figura 2: guaiamum capturado numa ratoeira. Foto: Fabiano Ribeiro/Arquivo do projeto
Figura 3: acompanhando Jorge na paisagem do guaiamum no estuário do Rio Goiana: área de capim com mata alagável ao fundo. Foto: Pedro Silveira/ Arquivo do projeto 
A maioria das ratoeiras que Jorge armou, entretanto, está mais à frente, numa área de mata alagável (Figura 3), com plantas como o dendê, o mulungu e o angico. Jorge vai me explicando sobre essas plantas, ao mesmo tempo em que me mostra os guaiamuns que recolhe nas ratoeiras, comentando sobre seu tamanho e sexo, e se estão gordos ou magros. Me explica que as características de sexo e tamanho podem ser avaliadas pelo tamanho do buraco, que ele mede no olhar ou com os dedos, e também pelas características das fezes dos animais, que eles depositam na entrada da toca. Há diferença na abundância e no comportamento dos guaiamuns durante o inverno chuvoso e durante o verão. Jorge me dá muitos detalhes sobre o comportamento dos guaiamuns. Ele comenta, em especial, sobre os possíveis motivos pelos quais os animais escaparam da armadilha, às vezes pelas pelas características e condições que ele atribui ao indivíduo (por exemplo, "está muito gordo e não quis sair"), às vezes por sua própria esperteza e artifícios ("ele não quis entrar na ratoeira", "ele arrebentou a liga").

Jorge diz que conhece muito bem todas aquelas matas. "É como se fosse a minha casa”. Ele deixa sinais em sua passagem, para orientação, quando acha necessário. Diz que cada pescador tem seu sinal característico; o dele é um pequeno talho na casca de árvores, em certa altura do tronco. Jorge, como quase todos os gaiamunzeiros, trabalha de maneira solitária. Ele é capaz de reconhecer as pegadas de outros pescadores e avaliar há quanto tempo estiveram ali. Diz que se encontra outro pescador trabalhando na área onde chega, se desloca para outro local. Não se pode pegar a ratoeira de outro pescador (muitos pegam, e esses são considerados "ladrões de ratoeira"), mas se um pescador abandona uma ratoeira em que o guaiamum foi capturado, Jorge sente-se no direito de recolher o animal e deixar a ratoeira no local. Deslocar-se para outro ponto é uma maneira de evitar conflitos, e evitar conflitos é uma diretriz de sobrevivência para quem anda sozinho pelos manguezais. Jorge diz que conhece a maioria dos pescadores de guaiamum que trabalha nas mesmas áreas que ele.

Apesar de conhecer bem toda a paisagem do Rio Goiana e saber se deslocar por entre os canais do manguezal até a foz do rio, sua área de trabalho costuma ser nos arredores do local que visitamos. Após recolher os guaiamuns presos nas ratoeiras e repor as iscas, Jorge faz uma segunda vistoria nas ratoeiras reinstaladas, pois várias delas já capturaram novos guaiamuns. Ao recolhê-los, Jorge os amarra com a casca de um arbusto abundante na vegetação, conhecido por imbira (a espécie botânica é provavelmente Hibiscus pernambucensis), ou coloca os animais dentro de um saco de ráfia cheio de folhas de palmeira ou de dendê, para que os animais não se agridam, de modo a amarrá-los quando chegar em casa.

Os animais capturados durante os dias úteis da semana ficam guardados na casa de Jorge até a sexta-feira, quando um atravessador, que é seu parente e ex-pescador, compra a produção para revender a um outro atravessador que comercializa os guaiamuns ainda vivos no sábado em uma feira livre em Olinda, a aproximadamente $60 \mathrm{~km}$ dali. $\mathrm{O}$ preço de uma unidade de guaiamum na feira é aproximadamente o dobro do valor que Jorge recebe do atravessador.

Além do comércio nas feiras, há algumas décadas o guaiamum passou a ser,
9 Imbira é um nome de origem indígena dado, no Brasil, a diversas plantas cuja fibra da casca pode ser usada como corda ou cordão. 
junto com o caranguejo-uçá, comercializado em restaurantes frequentados pela classe média e alta da região. Os restaurantes que servem essas espécies de caranguejos são frequentemente alvo de fiscalização por parte dos órgãos ambientais, e há uma tendência a demandarem animais de tamanho regulamentar e do sexo masculino. Para suprir tal demanda, alguns grupos de pescadores de guaiamum do Rio Goiana, especialmente os de Caaporã, no lado paraibano do rio, passaram a realizar excursões em grupo para capturar guaiamuns em outros estados, indo ao Rio Grande do Norte, ao Sul da Bahia e até mesmo ao Rio de Janeiro e São Paulo.

No estuário do Rio Goiana há guaiamuns nas áreas adjacentes aos manguezais e também na ilhas que existem dentro dos manguezais. A maior dessas ilhas, conhecida como Tiriri ou Itiriri, foi transformada, no início da década de 1990, num enorme conjunto de viveiros de camarões de uma empresa (Figura 1). A ilha foi completamente desfigurada pela construção dos grandes tanques de criação, e suas bordas, onde ainda ocorrem guaiamuns, tem o acesso proibido aos pescadores pelos vigias da empresa.

Estimamos, a partir de nossa experiência de pesquisa, que o número de pescadores de guaiamum no estuário do rio Goiana deve estar na faixa de 100 pessoas, quase todas do sexo masculino. Eles vivem na área urbana de Goiana, como Jorge, mas também em outras povoações pesqueiras localizadas rio abaixo, principalmente em Tejucopapo e São Lourenço, no lado pernambucano do rio, e no pequeno município de Caaporã, no lado paraibano.

\section{Guaiamuns, pescadores quilombolas e fazendas nos manguezais em São Francisco do Conde (BA)}

Morador do Quilombo Dom João, Marcos também aprendeu a pegar guaiamuns quando criança, na fazenda onde nasceu, no município de São Francisco do Conde, Bahia. Filho de um casal empregado que morava na fazenda, Marcos cresceu na condição de agregado, conjugando, desde cedo, suas habilidades enquanto trabalhador de fazenda e pescador de guaiamum. Levou a vida nessa condição: a de trabalhar para diferentes fazendeiros e em diferentes empreitadas e pegar guaiamum para consumo próprio e venda em pequena escala. Há 20 anos decidiu dar exclusividade à sua condição de gaiamunzeiro. A partir daí passou a "não ter mais patrão" e ser conhecido como um dentre os principais pescadores de guaiamum da região.

A fazenda onde Marcos nasceu está localizada em uma área de manguezal conectada ao quilombo Dom João pelo rio homônimo, que deságua na Baía de Todos os Santos. Ela remete aos domínios fundiários de uma família de importantes barões escravocratas da cidade que colonizaram a então Vila de São Francisco do Conde nos idos do século XVIII, figurando como seus proprietários por mais de 200 anos. A arquitetura colonial da fazenda ainda hoje compõe a paisagem do lugar, junto às áreas de plantio de cacau, cana e banana, entremeadas por pequenos rios, roças, trilhas e caminhos que configuram as paisagens de manguezal.

Hoje em processo de tombamento pelo Governo do Estado, essa fazenda é tida como símbolo da História Colonial contada com orgulho pela oficialidade da cida- 
de, que tende a suprimir as narrativas de violências da escravidão e seus efeitos no cotidiano dos seus descendentes, sobretudo a população negra e pobre, como a que vive da pesca de crustáceos e moluscos no mangue. Para além de símbolo de uma história colonial, essa fazenda é também um dentre os tantos territórios históricos e atuais de homens e mulheres que, quase imperceptíveis como Marcos, se dirigem diariamente para pescar guaiamum, caranguejo, siri, aratu e sururu, e outras variações da pesca no mangue.

Paisagem de ocorrência de guaiamum, a fazenda teve parte de suas áreas de encosta desmatada para o aumento de pastagem para gado. $O$ desmatamento determinou, segundo relatos de pescadores, a diminuição dos guaiamuns e, portanto, dos gaiamunzeiros que percorrem as encostas. Além do desmatamento das fazendas, há um crescente movimento de interdição do acesso às áreas de pesca por parte dos fazendeiros locais. Pressões impostas por esses têm dificultado o livre acesso às áreas tradicionais de pesca no manguezal. Tal situação, além de exprimir o poderio dos grandes proprietários e a concentração fundiária da cidade (onde 90 $\%$ da malha territorial é ocupada por 3 matrículas), impulsionou a articulação de alguns pescadores com o movimento pelos direitos quilombolas e aos territórios pesqueiros, assessorados pelo Conselho Pastoral dos Pescadores o CPP - e pelo Movimento dos Pescadores e Pescadoras Artesanais - o MPP (Geografar, 2015).

Marcos, bem como outros moradores de Dom João, figura como importante interlocutor desse movimento, reivindicando o livre acesso à pesca nas áreas de mangue. Fruto dessa mesma articulação é o processo de reconhecimento quilombola da comunidade de Dom João, em curso desde o ano de 2008 e marcado por perseguições aos moradores por parte dos poderes públicos locais, o que implicou a derrubada de casas, interrupção de fornecimento de luz elétrica e água, bem como desassistência dos programas sociais ligados à saúde e à educação. Trata-se, portanto, de um engajamento político que tem em vista o reconhecimento de seus direitos enquanto pescadores e quilombolas a partir de nova uma recategorização dos lugares de vida e habitação, configurando uma ontologia política dos territórios de diferença (Escobar, 2015).

Hoje reconhecido quilombo, Dom João foi o nome de um engenho de açúcar com trabalho escravo relacionado, também, a famílias de poderosos barões da cidade (Barickman, 1998-1999), transformado em usina a partir dos anos 1920 (Pinto, 2016). O lugar remete aos domínios territoriais de antigos engenhos de açúcar do período colonial, o que justifica a toponímia do local estar repleta de referências dessa cadeia produtiva, como Engenho Novo, Engenho Velho, Engenho D’água e Engenho de Cima. Nas margens do rio Dom João estava o conhecido Porto Dom João, responsável pelo escoamento do açúcar produzido com destino a Salvador. Como veremos mais adiante, além do açúcar, nas paisagens de Dom João estão inscritas a história da cadeia petrolífera nacional.

Em meio ao imperativo territorial do açúcar, da cana e da fazenda, o mangue sempre compôs a realidade de vida dos moradores, como Marcos, seus parentes, vizinhos e antepassados, conciliando o trabalho de peão de fazenda ou de empregado fichado nas empresas com a de pescador. Embora a captura de guaiamum 
seja prática comum e até corriqueira entre os moradores de Dom João, somente Marcos e José fazem desse tipo de pescaria, atividade exclusiva para obtenção de renda. $\mathrm{O}$ último, um jovem de 25 anos aproximadamente, tem intercalado, nos últimos meses, o trabalho de mangue com empreitadas ocasionais, como pedreiro, que the rende um dinheiro extra. Há uma tendência de pescadores de guaiamum abandonarem alguns meses a pesca, caso consigam trabalho em outro lugar. Assim como há uma tendência de moradores desempregados da cidade passarem a pescar guaiamum para segurança alimentar ou renda. Essa condição atual de gaiamunzeiro em dedicação exclusiva confere a Marcos um lugar de referência na cidade.

Marcos costuma pescar sozinho: logo cedo ruma em direção às áreas de mangue, de bicicleta ou a pé, retornando no início da tarde, por volta das 13 horas. Utiliza, como o pescador Jorge, do Rio Goiana, ratoeiras para capturar os animais. Dona Luisa, importante liderança de Dom João, diz que gaiamunzeiros, caranguejeiros e marisqueiras, incluindo-a, são pescandadores, por praticarem um tipo de pesca que se faz andando.

Andar por entre fazendas, encostas e cercas, percorrer caminhos próximos ou distantes de suas residências até chegar ao lugar escolhido, atravessar rios a canoa, caminhar por horas entre áreas de encosta e mangue úmido à procura dos buracos, na arrumação das armadilhas, sozinho ou em dupla ou trio, mapear e colher frutos para isca e engorda, é a condição da pesca de guaiamum dos habitantes da região. Não há um território fixo que ligue determinado pescador a determinado lugar. Moradores de Dom João podem pegar guaiamum no Trinta e Um; moradores de Campinas pescam na Baixa Fria; moradores da Baixa Fria rumam ao Marapé ou a Dom João (Figura 1). Embora a proximidade da residência com determinado lugar de mangue seja fator importante, ela não fixa o pescador em um ponto único de pesca. Há variáveis, como a possibilidade de uma área de pesca já estar batida, ou seja, ter os guaiamuns já capturados em seus buracos por outros pescadores nos dias anteriores, determinando a diminuição da ocorrência dos animais.

\section{O berçário de Guaiamum e a ressurgência nas ruínas do petróleo}

No quintal de sua residência, Marcos possui um tanque de engorda dos guaiamuns feito com material reaproveitado de refrigeradores. Esse tanque no Recôncavo recebe o nome de viveiro, enquanto em Pernambuco e Paraíba chama-se caritó. Ali os animais, transportados do mangue em um saco de ráfia, são alimentados com folhas e frutos, principalmente do dendezeiro. Com isso, os guaiamuns engordam e podem ser mantidos por alguns meses, até serem comercializados. Marcos vende o pescado para fregueses que vem à sua casa, além de fazer entrega no próprio município de São Francisco do Conde e cidades vizinhas, como Candeias, Santo Amaro e Salvador.

No mesmo quintal onde recebe os clientes e amigos, Marcos concebeu e criou, há duas décadas, um berçário de reprodução de guaiamuns. O berçário foi construído por sobre as ruínas de uma das antigas bases de refino do petróleo em Dom João, hoje desativada. A história da exploração de petróleo em Dom João remete aos anos 1950, inaugurando a cadeia petrolífera que então nascia no Brasil. Não é 
por acaso que a cidade, território com o maior contingente populacional autodeclarado "preto" do Brasil (IBGE, 2010) figura, por conta dos royalties do petróleo, como um dentre os municípios com a maior renda per capita nacional. A riqueza trazida pelo "tesouro negro", como é conhecido, não implicou uma melhora na qualidade de vida dos seus cidadãos, haja vista São Francisco do Conde também responder por um elevado índice de desigualdade social (Sansone, 2007; Geografar, 2015). Por isso, além de relacionadas à história do açúcar e da fazenda, as paisagens de Dom João inscrevem também a história do petróleo, e com ela formas de precarização da vida.

Pela presença da cadeia petrolífera nacional, as áreas de manguezal da cidade são ocupadas tanto por novas e desativadas estruturas da Petrobras quanto pela presença do que seus moradores chamam de prainha, áreas abertas de manguezal com a vegetação morta pela contaminação por vazamento de petróleo (Figura 4). As paisagens da prainha da cidade são reconhecidas pela ausência das espécies de árvores de mangue e, portanto, das muitas vidas que ali estão a elas relacionadas. Ou seja, as paisagens arruinadas do manguezal e suas encostas contam a história do petróleo na cidade, justamente quando nela não se encontram mais as espécies de árvores de mangue e a malha de vidas e elas conectadas. Quando o petróleo destrói o mangue, não há caranguejos, aratus, guaiamuns, ostras e sururus. Sem esses, não há a presença dos pescadores artesanais e a malha de vidas que conformam o território pesqueiro. Com o petróleo derramado e vazado, a vida se torna difícil e hostil às espécies que coabitam o mangue, incluindo a população negra de São Francisco do Conde.

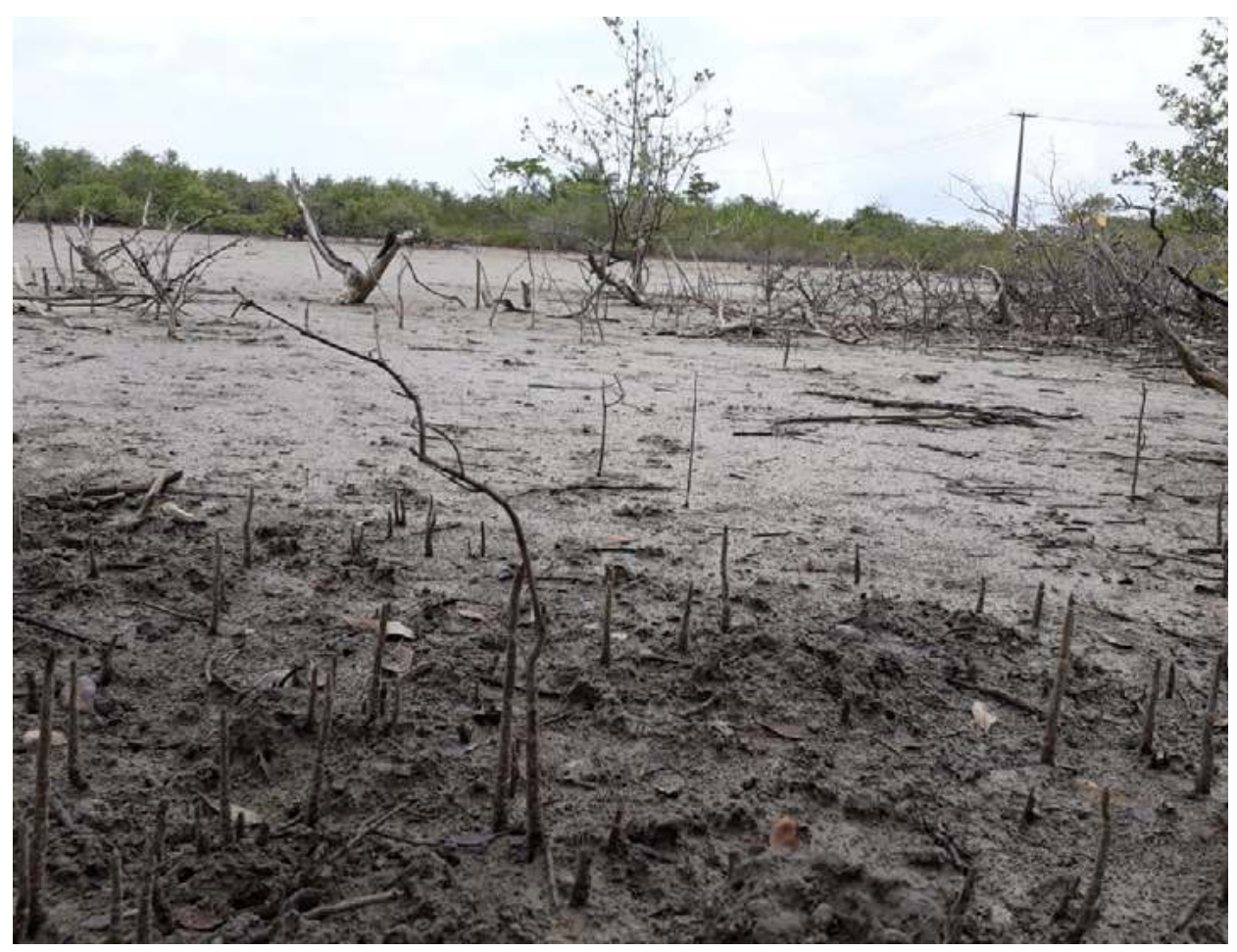

Figura 4: "prainha": área de manguezal degradada pelo impacto da indústria petrolífera. Foto: Rafael Buti/Arquivo do Projeto

Embora não esteja em funcionamento, parte das estruturas do petróleo e do açúcar continua nas paisagens de Dom João: as ruínas do ancoradouro para os 
barcos, as vigas da caldeira de petróleo, a chaminé da usina, o cimento da lavagem de caminhão, compõem o ambiente das casas, lugar de residência de aproximadamente 80 famílias. Antes da chegada da Petrobrás, parte das atuais áreas residenciais era ambiente de lama e mangue mole, como dizem, lugar impraticável para que humanos construíssem casas e guaiamuns caminhassem e abrissem buracos. Seguidos processos de aterramento para exploração e transporte do petróleo produziram não somente a contaminação do mangue e a mortandade multiespecífica, mas a criação de um ambiente também favorável à ocupação de humanos e guaiamuns. Trata-se, como relata o próprio Marcos, de "uma encosta feita com tauá", uma espécie de argila ou areia misturada com dejetos da indústria petroleira e material do mangue escavado e soterrado pelos tratores (Figura 5). Segundo o pescador, o que permitiu que guaiamuns migrassem para esse novo ambiente foram as andadas.

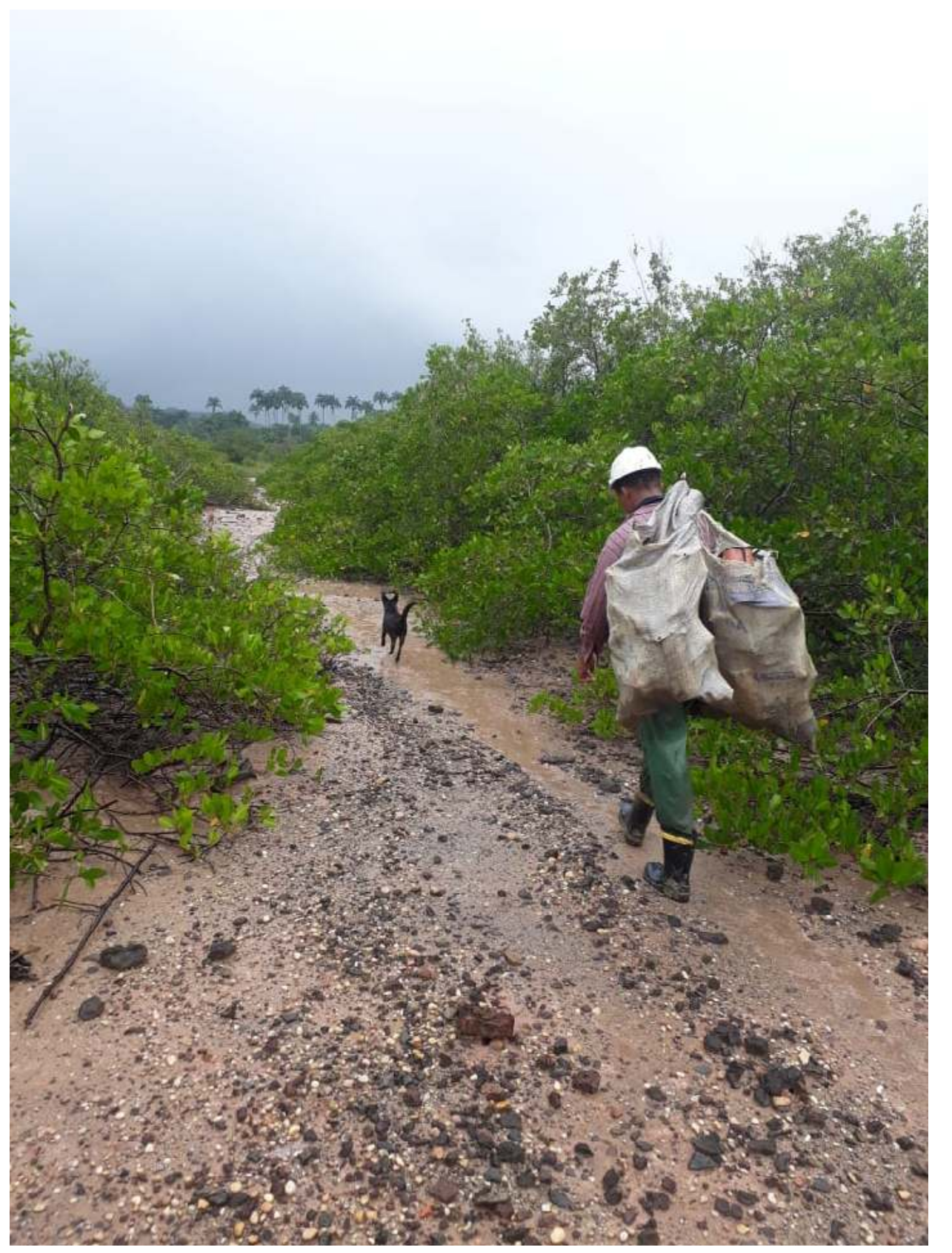

Figura 5: acompanhando Marcos na paisagem do guaiamum em São Francisco do Conde: caminhando sobre área aterrada pela Petrobrás. Foto: Rafael Buti/Arquivo do Projeto 
Por ocupar as ruínas do açúcar e do petróleo e fazer de um lugar contaminado, um ambiente de reflorescimento de vida multiespecífica, moradores de Dom João como Marcos estão inseridos no que Ana Tsing (2019, p. 226) chama de ressurgência, "o trabalho de muitos organismos que, negociando através de diferenças, forjam assembleias de habitabilidade multiespécies em meio às perturbações". Guaiamuns e quilombolas habitarem as ruínas do açúcar e do petróleo implica ressurgir nas paisagens conformadas pela devastação das fazendas e da indústria petroleira, e propor como vida o existir nos mundos impostos pelo latifúndio, pela contaminação, suas ruínas e cercas.

O berçário de guaiamum desenvolvido por Marcos em seu quintal a partir de seus conhecimentos pode ser entendido como uma prática de ressurgência. Trata-se de uma cavidade de um metro de profundidade por um metro e meio de largura cercada por tijolos e coberta por uma tela, cavado há mais de vinte anos na antiga viga de aço que sustentava uma refinaria de petróleo bruto extraído das profundezas do manguezal (Figura 6). Durante as duas primeiras andadas nas luas de janeiro e fevereiro, Marcos traz do mangue para seu quintal as gaiamunas chocas, ou patachocas, como são conhecidas as fêmeas ovadas. Ao colocá-las no berçário, ele as mantém protegidas até a lua cheia de março, conhecida como maré de março, quando as águas atingem seu ápice, correspondendo ao seu período de desova. A proximidade do berçário com o rio permite que aquele seja mantido pelo ciclo da maré.

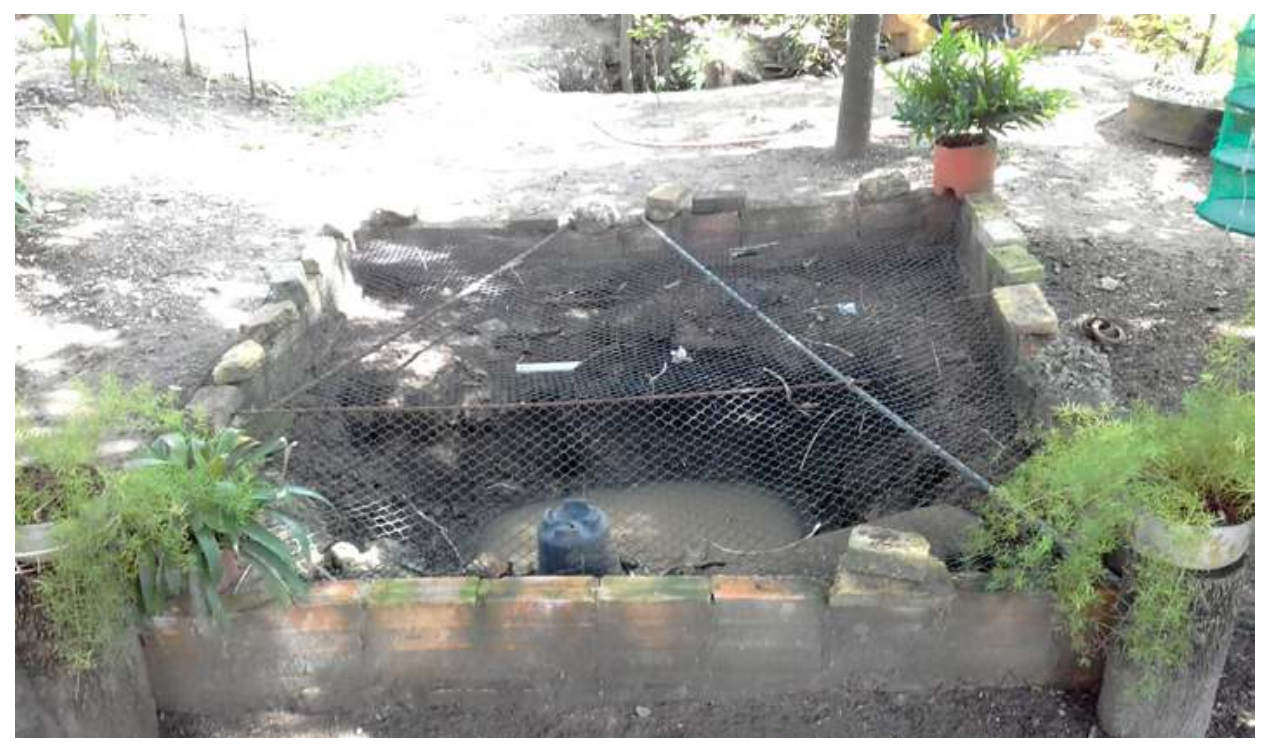

É no berçário de gaiamunas que Marcos cuida das fêmeas ao longo dos anos. Alimenta-as, além de regular a água e manter relação, diálogo e cuidado com os buracos dos guaiamuns do entorno, alguns dos quais, segundo o mesmo, abertos pelos filhotes ali nascidos, que saem espontaneamente do berçário pelas frestas dos tijolos.

O que motivou a criação do berçário foi a percepção da diminuição da ocorrência de guaiamuns diante de uma tripla condição do manguezal: o desmatamento das fazendas; a contaminação por petróleo; e o desemprego na cidade, motivo que conduz sua população pobre às áreas de pesca para adquirir alimento e renda. A percepção da diminuição da população de guaiamuns é compartilhada por boa
Figura 6: "berçário" de guaiamuns no quilombo Dom João, São Francisco do Conde. Foto: Pedro Silveira/Arquivo do projeto 
parte dos pescadores e pescadoras da cidade com os quais mantivemos interlocução. Ao trazer as fêmeas para o berçário, Marcos entende contribuir para sua proteção e reprodução da espécie.

O berçário parece configurar uma iniciativa local, criativa e propositiva de cuidado com o mangue e recuperação da espécie guaiamum por parte de um gaiamunzeiro. Em outras palavras, Marcos é, por conta própria, um pescador-pesquisador do manguezal preocupado com seu presente e futuro. Além do berçário e do viveiro, em seu quintal há inúmeras espécies vegetais, plantadas por ele mesmo e por seus parentes, ou nascidas de forma espontânea, configurando o que um grupo de estudantes da Unilab tem chamado de manquintal: este espaço de vida das populações pesqueiras que conjuga áreas de manguezal com quintais e outros ambientes domésticos ${ }^{10}$. O manquintal é um lugar multiespecífico e típico dos coletivos marcados pelo que Escobar (2015) chama de ontologia relacional, em que humanos e não-humanos formam parte integral dos mundos em suas múltiplas inter-relações: o que de alguma forma confunde as fronteiras rígidas demarcadas no projeto de modernidade baseado na separação natureza-cultura (Latour, 1994).

Curiosamente, um discurso assentado na separação ontológica entre natureza e cultura é justamente o que vem fundamentando a justificativa da Prefeitura na retirada dos moradores de Dom João. A Secretaria do Meio Ambiente acusa os moradores de serem degradadores do ambiente, por ocuparem um local de manguezal e Área de Preservação Permanente (APP). Os relatórios produzidos pelo órgão não levam em conta a relação vital que liga humanos e não humanos nas áreas de manguezal da cidade, bem como a contribuição dos habitantes de Dom João na recuperação de uma área degradada pela cadeia petrolífera, escamoteando a condição feita e arruinada pelo petróleo das paisagens do lugar, bem como a escala de devastação impetrada pelos vazamentos. Não levam em consideração também os direitos de autodeterminação das comunidades quilombolas que, além de possuírem ancestralidade negra e vinculação com o território, são reféns históricos da desigualdade fundiária e racial na cidade. Como disse uma liderança de Dom João, a "conta cai sempre do lado do mais fraco", o que explica uma frase proferida em um ato de repúdio a um vazamento de petróleo ocorrido em maio de 2018, quando partes do mangue e das áreas residenciais foram invadidas por petróleo, ocasionando a mortandade de espécies e arruinamento dos ambientes: "petróleo pode, preto não, morar em Dom João".

\section{"Criticamente em perigo": a pesca do guaiamum na paisagem institucional}

No ano de 2007, o estuário do Rio Goiana foi transformado em uma Reserva Extrativista (Resex) ${ }^{11}$. A reserva é gerida por um Conselho Deliberativo com a característica de ser soberano em suas decisões. Este conselho funciona de maneira representativa e tem maioria de representantes dos pescadores artesanais, que são, no linguajar institucional, os beneficiários. Há também representantes, em minoria, que não são beneficiários. No caso da Resex Acaú-Goiana, há representantes de instituições de pesquisa, das prefeituras, de ONGs assessoras e também de empresas que funcionam nos arredores da reserva. O Conselho Deliberativo da
10 O manquintal surgiu como conceito elaborado pelos discentes Lauro Cardoso, Naiane Pinto, Margarida Berdo e Aldine Bathilon, do Curso de Licenciatura em Ciências Sociais, durante atividades de campo para a disciplina Laboratório de Saberes. A Unilab é a Universidade da Integração Internacional da Lusofonia Afro-brasileira.

11 As reservas extrativistas são unidades de conservação ambientais administradas pelo Governo Federal por meio do Instituto Chico Mendes de Conservação da Biodiversidade, (ICMBio), que beneficiam as assim chamadas comunidades tradicionais, destinando a elas o usufruto preferencial de paisagens biodiversas onde habitam. 
Resex Acaú-Goiana começou efetivamente a funcionar somente a partir de 2013, ou seja, seis anos depois de sua criação.

Um dos autores deste artigo acompanhou o processo de criação da Resex Acaú-Goiana (Silveira et al., 2010) e desde 2016 é conselheiro, representando a instituição onde trabalha. A Resex Acaú-Goiana foi criada no contexto da movimentação dos pescadores artesanais organizados nas colônias e associações de pescadores, apoiados por organizações assessoras, como o Conselho Pastoral dos Pescadores (CPP), além da participação de funcionários do Ministério do Meio Ambiente e de pesquisadores acadêmicos. No estado de Pernambuco, além de Acaú-Goiana, foram propostas pelos pescadores a criação de mais duas Resex e uma Reserva de Desenvolvimento Sustentável (RDS), sendo que apenas a Resex Acaú-Goiana foi efetivamente criada (Silveira et al., 2010).

A proposta de criação de uma reserva extrativista no estuário do Rio Goiana gerou uma enorme resistência de políticos e de empresários com influência na política local e regional. Como um dentre os vários exemplos, no intuito de barrar o estabelecimento da Resex, algumas empresas canavieiras enviaram para as audiências públicas funcionários em ônibus portando faixas contra a criação da mesma. As usinas de cana têm um histórico de décadas, senão séculos, de impactos nos manguezais do Rio Goiana, que incluem queimadas, plantio de cana até a margem dos cursos d'água, derramamento de resíduos do processamento da cana, além da contaminação por agrotóxicos (Silveira et al., 2013).

O lobby das empresas de carcinicultura, que vinham desde a década de 1990 estabelecendo tanques de cultivo de camarões no entorno e dentro das áreas de manguezais em várias partes do litoral nordestino, com conflitos com pescadores e ambientalistas, foi outra força política contrária à criação das Resex em áreas costeiras, bem como o próprio Governo do Estado de Pernambuco. Esse Governo, além de politicamente comprometido com canavieiros e carcinicultores, tinha planos de desenvolver na região de Goiana um polo industrial, como de fato o fez, parcialmente, no período imediatamente posterior à sua criação, com o estabelecimento de uma fábrica automotiva e outros empreendimentos.

Diante de tais dificuldades conflitivas, as equipes ligadas ao Ministério do Meio Ambiente, responsáveis por viabilizar a criação de Reservas Extrativistas tiveram como estratégia negociar que estas fossem estabelecidas apenas nas áreas pertencentes à União. Evitariam assim ampliar os conflitos e arrastar a regularização fundiária por muitos anos, sobretudo por conta dos processos de desapropriação do imóvel de particulares. Essa perspectiva pragmática gerou efeitos negativos e contrários aos seus próprios objetivos, e especialmente importantes para a ecologia política do guaiamum.

O primeiro desses efeitos foi a delimitação das fronteiras da Resex Acaú-Goiana coincidindo com os limites do manguezal ao longo do Rio Goiana (Figura 1). Isso propiciou que grande parte das áreas habitadas pelos guaiamuns e áreas de trabalho dos pescadores ficasse localizada fora da reserva. $O$ segundo foi a existência de uma enorme área de exclusão localizada no perímetro interno da Resex, a Ilha de Itiriri, onde funciona o maior empreendimento de carcinicultura 
do estado de Pernambuco, uma área que faz parte do território histórico de uso tradicional dos pescadores. Toda a borda dessa ilha é potencialmente área de ocorrência de guaiamuns.

No âmbito da Resex, o ICMBio, respaldado pelo Conselho Deliberativo, tem tomado algumas medidas importantes de controle da ação das empresas canavieiras e de carcinicultura, principalmente pela aplicação de multas e verificação de regularidade de funcionamento. Contudo, a ação do órgão é bastante limitada fora dos limites da unidade, especialmente em áreas particulares.

A linguagem institucional do funcionamento da Resex versa sobre a existência de regras sobre o que é legalmente permitido, e presume-se que tais regras sejam pactuadas no plano local da reserva, por meio de um documento chamado Acordo de Gestão, que deve ser aprovado pelo Conselho. No entanto, na prática essas regras circunscrevem-se em um campo de possibilidades restrito, pois se encontram subordinadas ao escopo da legislação nacional e estadual, o que acaba por engessar as possibilidades de produção de soluções locais criativas de uso e conservação das espécies, via de regra divergentes das portarias e instruções normativas editadas a partir de Brasília.

Além disso, ao longo de seu funcionamento, a linguagem institucional da Resex precisou ser incorporada pelas lideranças dos pescadores e demais membros do Conselho. São categorias bastante distantes dos conceitos acessados na vida cotidiana dos pescadores, que precisam a todo tempo vir acompanhadas de processos de tradução. Os pescadores de guaiamuns, como Jorge, participaram historicamente muito pouco dos debates da Resex, tendo também baixa representatividade política no conjunto dos pescadores artesanais, embora se vejam representados pelas associações e colônias de pescadores, e respondam quando são convocados a reuniões específicas sobre sua atividade.

A história da politização da pesca do guaiamum, na Resex Acaú-Goiana, passa pelo debate sobre a margem de liberdade para a formalização de regras locais. Por muitos anos não havia nenhum tipo de legislação a respeito dos guaiamuns. Em 2003 foi editada uma portaria do Ibama (53/2003) criando regras para captura no Sudeste do Brasil, ao passo que em 2006 a Instrução Normativa 90/2006 foi publicada para a Região Nordeste. A edição dessas regras, acreditamos, vieram a reboque do estabelecimento de regras para a captura do caranguejo-uçá (Ucides cordatus), outra espécie de caranguejo que ocorre em maior densidade na região, mas que é típica da lama do interior dos manguezais (Alves e Samain, 2004; Souto, 2008), configurando-se em uma outra ecologia política da pesca. O fato é que, até então, a pesca do caranguejo-uçá já se encontrava em debate no âmbito das políticas públicas de conservação ambiental, ao contrário do guaiamum.

Essas regulamentações indicavam, basicamente, que só poderiam ser capturados guaiamuns machos, com carapaça de medida superior a uma largura variável entre 6 e $8 \mathrm{~cm}$, a depender do estado, e que eles não poderiam ser capturados nos dias em que saem para se reproduzir (a andada). A ratoeira foi considerada um petrecho permitido. Não há dados sobre os efeitos dessa regulamentação. Por nossa percepção em campo, parece ter tido algum efeito sobre a comercialização 
do guaiamum em restaurantes, onde havia alguma fiscalização, a reboque da fiscalização do caranguejo-uçá, agindo sobre os critérios de compra dos atravessadores. Mas as outras formas de venda, em feiras ou diretamente ao consumidor, não parecem ter sido afetadas. Os critérios da legislação tinham certa legitimidade frente aos pescadores, mas nem sempre eram adotados, e nem sempre eram conhecidos. A fiscalização da pesca do guaiamum era, até então, praticamente inexistente. Os pescadores de guaiamum continuavam suas atividades segundo os mesmos procedimentos costumeiramente adotados.

A discussão do Acordo de Gestão, que aconteceu entre 2012 e 2015, introduziu publicamente a pesca do guaiamum na Resex Acaú-Goiana. Pela primeira vez, pescadores de guaiamum foram chamados a participar de uma discussão a respeito de sua atividade, que foi feita junto com outras modalidades de pesca.

Em seu texto (Portaria ICMBio 851/2017), o acordo local repetia o que dizia a legislação vigente a respeito da liberação da armadilha tipo ratoeira e do tamanho mínimo de $6 \mathrm{~cm}$. Inseriram-se ainda outras regulamentações: a suspensão da captura em uma área específica da Resex; a proibição do uso de fogo para captura; questões relativas ao transporte; a definição de uma quantidade máxima de guaiamuns por família por dia, indicada como 50 indivíduos, quantidade considerada razoável para um dia de trabalho de um pescador.

Em 2014, enquanto o Acordo de Gestão era discutido, surgiu uma questão que afetaria não só os pescadores de guaiamum da Resex Acaú-Goiana, como de todo o litoral brasileiro. Tratava-se da Portaria n.445/2014 do MMA, que incluía o guaiamum, junto a várias espécies de peixes marinhos, na lista das espécies ameaçadas de extinção. O guaiamum era incluído numa categoria denominada criticamente em risco, que implicava a proibição completa de sua captura. Essa portaria passou por uma série de anulações e revalidações jurídicas, em grande parte protagonizadas por agentes da pesca industrial de espécies de peixes que também eram afetados pela Portaria 445.

Em 2016, a questão da proibição da pesca do guaiamum foi apresentada da seguinte forma pela equipe do ICMBio em uma reunião do Conselho Deliberativo: por conta da iminente proibição da pesca do guaiamum (havia naquele período uma liminar suspendendo a portaria, que seria derrubada em seguida), o ICMBio em Brasília sugeria que o Conselho retirasse os itens sobre a pesca do guaiamum do Acordo de Gestão, sob a alegação de que caso a proibição se efetivasse, o Acordo de Gestão não seria aprovado pelo Ministério.

O Conselho criou então um Grupo de Trabalho (GT) formado por representantes dos pescadores, de pesquisadores, do Conselho Pastoral dos Pescadores e do ICMBio, que emitiu um parecer favorável à manutenção dos referidos itens. Argumentava-se que a Resex tinha por objetivo proteger os modos de vida tradicionais de seu território, e que um documento do próprio Ministério indicava que o principal problema do declínio do guaiamum era a chamada perda de habitat, ou seja, a destruição dos ambientes onde vive o guaiamum.

O documento do MMA referido pelo relatório do GT chama-se "Texto-base para recuperação do caranguejo-guaiamum” (Galli, 2016), que havia sido publici- 
zado no período em que esses debates aconteciam, e que já indicava a preparação de uma estratégia nacional de flexibilização da proibição, dada a importância da pesca do guaiamum como atividade de comunidades pesqueiras. Esse documento indicava também a insuficiência de dados técnicos sobre os estoques de guaiamum. Vale dizer que as discussões com representantes dos pescadores e com pescadores de guaiamum apontavam para uma redução no tamanho médio e diminuição na quantidade de guaiamuns, mas não uma situação que indicasse que a espécie estaria "criticamente em perigo".

Assim, o Conselho, por unanimidade e com apoio da equipe gestora local, decidiu por manter o guaiamum regulamentado pelo Acordo de Gestão, instituindo uma Câmara Técnica de caráter permanente, que passou a acompanhar a questão do guaiamum e de outros crustáceos.

Os desdobramentos desses acontecimentos, até a redação deste artigo, foram que o Ministério do Meio Ambiente publicou em 2018 uma nova Portaria (n. 128) com o "Plano de recuperação do guaiamum", regulamentada, por sua vez, pela Portaria Interministerial n. 38/2018, que traz as "regras para o uso sustentável e para a recuperação dos estoques da espécie Cardisoma guanhumi”. 0 artigo 6 dessa última portaria dispõe que

"a pesca da espécie Cardisoma guanhumi somente será permitida nas unidades de conservação de uso sustentável ou em áreas manejadas vinculadas aos planos de gestão locais formalmente instituídos, que apresentarem análise prévia de viabilidade da pesca sustentável e compatível com a recuperação da espécie". Cria-se, portanto, a figura do plano de gestão local, um documento válido para uma área de manejo específica, pensada como sendo preferencialmente uma unidade de conservação de uso sustentável, abrindo possibilidade de inclusão de outros tipos de áreas manejadas quando "formalizad[a]s pelos órgãos da administração pública federal ou estadual competentes" (art. $\left.7^{\circ}\right)$.

Esse plano de gestão local envolve cinco procedimentos do tipo comando-e-controle estatal: cadastramento para identificação e autorização dos pescadores; monitoramento da pesca; diretrizes de fiscalização; medidas de ordenamento; avaliação. Em localidades que não apresentarem, até novembro de 2019, um plano com tais características, a pesca do guaiamum estará proibida, caso nenhuma outra regulamentação contrária seja publicada. Dada a dinâmica irregular das disputas políticas em torno da Portaria 455, isso não seria uma surpresa ${ }^{12}$.

A portaria reafirma ainda todas as regras preexistentes, tornando-as mais rígidas com relação ao tamanho mínimo que passa de 6 para $7 \mathrm{~cm}$ de carapaça, e com relação ao período de proibição de captura, que envolve duas semanas por mês (luas cheia e nova) entre dezembro e maio. A partir do novo panorama sobre a atividade do guaiamum, a Câmara Técnica dos Crustáceos da Resex Acaú-Goiana, reuniu-se diversas vezes ao longo dos anos de 2017 e 2018, realizando reuniões de esclarecimento da situação institucional e oficinas de mapeamento participativo
12 Durante o período de redação deste artigo, acompanhamos profundas mudanças nas políticas ambientais no Brasil, a partir da eleição de Jair Bolsonaro para a Presidência da República. Estão em pauta, por exemplo, a extinção de conselhos de participação popular, a fusão do ICMBio com - Ibama e também a revogação da Portaria 445. São alguns exemplos de eventos que alterariam a paisagem institucional da pesca de guaiamuns, porém não invalidariam a argumentação deste artigo. 
com pescadores de guaiamum nas localidades onde vivem os beneficiários da Resex. Terminou 2018 com a apresentação de um esboço do plano local de gestão nos termos exigidos legalmente, procurando trabalhar pragmaticamente para criar um documento que permita que a atividade de pesca do guaiamum prossiga na Resex Acaú-Goiana. Esse trabalho se encontra em andamento no momento em que este artigo é redigido.

\section{Os limites do disciplinamento da pesca de guaiamum}

Uma reflexão a partir da realização da pesquisa que dá origem a este artigo, concomitante à participação de um dos autores na Câmara Técnica dos Crustáceos, nos indica que a realização dos ritos institucionais de adequação ao Plano de Recuperação do guaiamum é um esforço pragmático para impedir localmente a proibição da pesca. Essa proibição, por sua urgência, gera a politização de uma questão antes invisível às políticas públicas: a ameaça à existência futura do guaiamum. Entretanto, os termos que balizam a produção do plano não têm efeito sobre o que nos parece - e parece também aos biólogos e aos pescadores - serem as principais questões a abordar, sejam elas, na linguagem técnico-científica, a perda de habitat e o uso sustentável dos estoques de guaiamum. A produção deste plano também não contribui para a valorização social nem econômica dos pescadores de guaiamum que, com toda razão, mostram-se desconfiados com os mecanismos de controle estatal e com o vaivém das determinações legais.

No momento em que este artigo é redigido, os pescadores hesitam em preencher a ficha de automonitoramento elaborada por um pesquisador que é também servidor da Resex, com o objetivo de cumprir uma das exigências do Plano de Recuperação. Os pescadores continuamente perguntam aos pesquisadores envolvidos no Conselho se a pesca do guaiamum "está aberta ou está fechada", e alternam entre a participação nos debates públicos e a estratégia de se retirar à invisibilidade política de seus engajamentos no manguezal.

Vale refletir sobre as diretrizes do Plano de Recuperação à luz dos argumentos do documento de 2016 do GT do Conselho da Resex Acaú-Goiana. Estamos tratando de uma espécie que habita locais especialmente sensíveis à degradação e ocupação desordenada, declarada como em ameaça crítica de extinção. A estratégia governamental encontrada, entretanto, não foi a de assegurar a conservação desses ambientes, mas a de identificar os pescadores e controlar a atividade de pesca. Esses pescadores, por sua vez, são parte de grupos humanos em alto grau de vulnerabilidade social e sujeitos de direito das políticas para comunidades tradicionais.

Não é nosso objetivo aqui realizar uma análise do funcionamento das agências estatais, que não são entidades monolíticas, e das políticas públicas, que envolvem diversas forças em disputa. $\mathrm{O}$ que nos salta aos olhos com relação à situação do guaiamum é a dificuldade de se propor uma política territorial que leve a sério a conclusão, no âmbito do próprio Estado, de que é preciso agir face à ameaça ao desaparecimento de uma espécie. Um dos motivos parece ser a subordinação estatal a interesses econômicos privados, que impede ações visando ao bem público que sejam conflitantes com tais interesses. $O$ outro parece estar relacionado à lógica 
estatal de gestão territorial que opera ou pela delimitação de um território sob controle estatal que não se conecta com processos da paisagem mais ampla; ou por mecanismos de comando-e-controle que, no fim das contas, o próprio Estado tem pouca capacidade de fazer cumprir. Esse tipo de lógica de operação, mesmo dentro de estruturas de participação como as reservas extrativistas, é muito pouco permeável às soluções criativas que podem ser formuladas pelos habitantes dos manguezais, em suas conexões com organizações assessoras, pesquisadores acadêmicos e gestores públicos.

\section{O Plano de Recuperação do Guaiamum em São Francisco do Conde}

Diferente do estuário do rio Goiana, os manguezais de São Francisco do Conde não estão inseridos em um contexto institucional de unidade de conservação. Até o momento em que este artigo é escrito, a discussão sobre o Plano de Recuperação do guaiamum não teve rebatimento entre os gestores e os pescadores da cidade. Primeiro porque o município não conta com políticas de manejo voltadas à pesca de guaiamum. Segundo porque, diferente do caso do Rio Goiana, não há na cidade espaços de discussão reservados a esse tipo de debate, como aqueles criados no âmbito de uma Reserva Extrativista, como os Conselhos, os Grupos de Trabalho e as Câmaras Técnicas.

O pouco que se sabe e que se tem feito acerca do tema se deve aos esforços de alguns pescadores articulados a duas diferentes e complementares redes de apoio: uma é o Conselho Pastoral dos Pescadores (CPP), que tem uma sede regional em Salvador e um histórico de assessoria aos pescadores da região; a outra é a Unilab, que tem há cinco anos o seu Instituto de Humanidades e Letras sediado às margens das áreas de manguezal no bairro da Baixa Fria, vizinha a Dom João.

Pode-se dizer que o gaiamunzeiro Marcos é um importante articulador dessa discussão em São Francisco do Conde, implicado que está nesses dois espaços. Ele tem se engajado nas atividades de recuperação do mangue e da espécie guaiamum a partir da interlocução com alguns projetos e atividades da Unilab e da CPP. Na Unilab, Marcos tem atuado como instrutor de aulas de campo junto às disciplinas e projetos desenvolvidos por um dos autores deste artigo. Nessas atividades acompanha discentes, docentes e outros colaboradores em visitas a áreas de manguezal em Dom João e seu entorno, ensinando sobre os ciclos do guaiamum, técnicas e territórios de pesca, bem como estratégias de recuperação do mangue diante dos efeitos nocivos da indústria petroleira, do desmatamento das fazendas e da sobrepesca de guaiamum. De modo bastante particular e solitário, Marcos tem buscado replantar mudas de mangue vermelho (Rizophora mangle) em áreas de prainha, a princípio sem sucesso.

Além disso, Marcos tem participado dos encontros da Articulação Subaé, coletivo formado por lideranças de quatro comunidades quilombolas do Recôncavo, membros da CPP e MPP da Bahia e pesquisadores universitários. Subaé é o nome do rio que atravessa o município de Santo Amaro, desaguando na Baía de Todos os Santos na divisa com São Francisco do Conde. Nos anos 1960, a Companhia Brasileira de Chumbo Brasil-Cobrac, subsidiária da multinacional Penarroya, instalou, em 
suas margens, uma fábrica de exploração de chumbo, o que ocasionou, por conta das atividades que duraram três décadas, um dos maiores desastres socioambientais ligado a metais pesados do mundo (Andrade; Moraes, 2013). Ao batizar-se de Subaé, a Articulação propõe reaver os direitos do pescador e dos territórios pesqueiros arruinados pelos vários agentes industriais no Recôncavo, incluindo o petróleo.

Para o coletivo, formado por pescadores e pescadoras de 40 a 65 anos de idade, moradores das comunidades de Dom João, Cambuta, Acupe e São Brás, a diminuição da ocorrência dos guaiamuns é efeito de um histórico de desmatamentos, degradação industrial e falta de políticas de controle da pesca e da sobrepesca, sobretudo as referentes ao caranguejo e ao guaiamum. Uma das pautas reivindicatórias do grupo tem sido lutar pelos direitos do gaiamunzeiros e caranguejeiros a partir do seguro defeso do guaiamum e do caranguejo-uçá ${ }^{13}$, por entenderem que as medidas trariam maior visibilidade e valorização desse segmento de pesca no mangue, bem como proteção das espécies nos períodos de reprodução.

Foi em outubro de 2018 que o plano de recuperação do guaiamum entrou na pauta da Articulação, o que determinou, até o início de 2019, cinco encontros para discutir a Portaria e organizar as atividades para a sua elaboração. As reuniões foram realizadas nos quilombos de Dom João, Acupe e São Brás, tendo como participantes gaiamunzeiros locais, pesquisadores e membros da CPP. Ao propor a construção do plano de recuperação nos referidos territórios quilombolas, a Articulação figura como uma iniciativa inédita no atual contexto de ordenamento do guaiamum, visto que as áreas que pretende cobrir não estão situadas nos limites de uma unidade de conservação, como no caso das Resex Acaú-Goiana e Canavieiras, onde os planos têm sido elaborados através de seus Conselhos Deliberativos.

A implicação disso é a dificuldade que os membros da Articulação têm tido na compreensão da Portaria, bem como os arranjos institucionais necessários para sua realização, visto tratar-se de um processo bastante trabalhoso que envolve a necessária articulação entre práticas e saberes tradicionais, científicos e jurídicos. Pretende-se fazer, ainda não se sabe de que maneira, o cadastramento dos gaiamunzeiros dessas localidades, um plano de monitoramento da pesca e um etnomapeamento dos territórios de guaiamum, algo inexistente naquele contexto.

Como uma primeira iniciativa de recuperação do manguezal aliada à preservação da espécie guaiamum no contexto da Portaria, os próprios pescadores vinculados à Articulação Subaé propuseram multiplicar o berçário de guaiamum de Dom João, o que culminou em reuniões de planejamento para a construção, bem como rodas de conversa entre pescadores ao redor do próprio berçário de Marcos. Em um primeiro momento, em novembro de 2018, Marcos recebeu os pescadores dos quilombos de Cambuta, Acupe e São Brás em seu quintal, explicando aos mesmos a história do berçário e seu funcionamento. Um mês depois realizou-se a construção do berçário em Acupe, no quintal de Dona Ana, pescadora do local.

Na ocasião, em torno de dez pescadores e pescadoras, junto a alguns dos seus filhos e filhas, se reuniram para construir o berçário, em uma dinâmica de trabalho coletivo que durou aproximadamente sete horas. Enquanto os homens escolhiam o local, cavavam o buraco e o contornavam com tijolo sob orientação de
13 O Governo Federal criou, no início dos anos 2000, um programa de seguro-defeso para beneficiar pescadores profissionais de espécies que passam por uma proibição de pesca por uma parte do ano, no caso o camarão e a lagosta. Há uma reivindicação de pescadores de caranguejos para que seja criado também um seguro-defeso específico para esse tipo de pesca. 
Marcos, as mulheres preparavam uma refeição, que foi servida no encerramento das atividades. No entorno do berçário foram plantados um pé de limão, um pé de tamarindo e um dendezeiro, para garantir sombra e alimento às gaiamunas e guaiamuns que futuramente poderão habitar o local. O sucesso da construção ainda está em análise. Segundo Marcos, vai depender da adaptação dos animais ao lugar, bem como a relação do berçário com os níveis da água. Os pescadores e pescadoras envolvidos compreendem que o berçário é uma iniciativa própria de manejo, que deve ser validada pelo poder público nos contextos das futuras fiscalizações.

\section{Os limites de uma política de conservação}

Vimos que no estuário do Rio Goiana há um ordenamento estatal do território, configurado no espaço da Resex. Vimos, acompanhando Jorge, que embora importante para proteger as áreas de manguezal dos avanços do agro e do hidronegócio, esse ordenamento não traduz ou cobre os fluxos dos territórios de guaiamum, uma vez que a área de pesca do animal vaza os perímetros da Resex, pela própria lógica de concepção de sua demarcação territorial. O fato de Jorge perambular pelo território pesqueiro para além da poligonal da Resex evidencia os limites da área protegida como lugar de incorporação dos modos de vida de gaiamunzeiros e guaiamuns.

Vimos também que o plano de gestão local do guaiamum é produzido na lógica do controle da pesca, não incidindo sobre a questão da perda de habitat. Vimos ainda que, operada pela agência estatal que trata das unidades de conservação ambiental, e na impossibilidade de outras agências estatais terem capacidade e interesse de lidar com essa questão, a forma de gerenciamento do plano de recuperação supõe que este seja feito a partir da gestão de unidades de conservação. Isso implica que, na prática, as unidades de conservação (ou outras "áreas manejadas") que forem capazes de produzir um plano de recuperação terão a pesca permitida, enquanto que na maior parte dos locais, ela provavelmente continuará existindo de forma ilegal.

Vimos com Dom João uma dupla sobreposição dos ordenamentos do Estado em relação ao território pesqueiro: de um lado, o poder público municipal reivindicando um dispositivo jurídico do ambientalismo preservacionista sobre o manguezal. A figura legal da Área de Proteção Permanente (APP) é acionada para proteger o manguezal e o rio, não dos humanos de maneira geral, mas de um tipo de humano: o pescador artesanal, majoritariamente o pescandador de manguezal, precarizado e invisibilizado pelas políticas públicas da pesca. $\mathrm{O}$ argumento da prefeitura instrumentaliza a expropriação dos quilombolas e não incorpora as realidades multiespécies que conformam os territórios pesqueiros, além de escamotear as duas principais forças predatórias dos modos de vida dos guaiamunzeiros e guaiamuns do lugar: a fazenda e o petróleo.

Do outro lado, descrevemos a reivindicação dos pescadores para a demarcação do território quilombola como figura jurídica que incorpora as realidades multiespecíficas e traduzem os saberes fundados nas ontologias relacionais, em que o manquintal, lugar da ressurgência em áreas arruinadas, atua como referên- 
cia importante e contrária à separação ontológica natureza/cultura, manguezal/ quintal. $\mathrm{O}$ fato de Marcos contribuir para a reprodução da espécie guaiamum e manejar os ambientes coproduzindo a agrobiodiversidade em áreas arruinadas nos ensina sobre os limites do preservacionismo como ferramenta que traduz as realidades dos territórios pesqueiros. E é justamente pela gramática política dos territórios pesqueiros, dos quais falaremos abaixo, que têm se movido estes homens e mulheres da pesca, conhecedores dos modos de vida de animais como os guaiamuns e de fluxos como os regidos pela maré.

Diante disso, os pescadores têm criado estratégias locais de cuidar dos guaiamuns e seus territórios, quer de modo costumeiro e espontâneo - a partir de uma ética cotidiana do cuidar, como o berçário e o replante do mangue - , quer no diálogo com os ordenamentos do Estado - como a própria proposição do plano de recuperação no espaço da Articulação Subaé e a inserção em uma rede maior de luta pelas comunidades quilombolas pesqueiras.

Vimos, por fim, que tanto na Resex Acaú-Goiana quanto nos manguezais do Recôncavo, há uma enorme dificuldade de se produzirem dispositivos legais e de gestão pública para legitimar as paisagens onde perambulam guaiamuns e gaiamunzeiros como territórios prioritários para conservação e uso sustentável de uma espécie que se quer preservar, e de uma categoria social vulnerável que conhece e usa essa espécie e está interessada que seus ambientes se mantenham íntegros. Nas duas paisagens que estudamos, encontramos manguezais em processo de contaminação e precarização, contrastante com sua característica de proliferação de vida aquática e sustento humano.

\section{Uma cosmopolítica do manguezal: territórios pesqueiros e a Mãe Maré}

Trouxemos do quilombo Dom João o conceito de pescandador, que se refere à perambulação pelas paisagens como forma de atividade vital dos pescadores $\mathrm{e}$ pescadoras de São Francisco do Conde, em especial dos gaiamunzeiros. Como estes, os gaiamunzeiros do Rio Goiana e de outros locais com os quais tivemos contato em nossa pesquisa são também pescandadores. Eles perambulam por territórios que veem como fluidos e de livre acesso, deparando com situações de interdição de circulação em propriedades privadas e públicas, em ambientes de precarização e de destruição das paisagens.

A perambulação dos pescandadores nos indica, portanto, que as áreas de vida e morte dos guaiamuns e de trabalho dos seus pescadores são paisagens de fricção (Tsing, 2004; 2012). Nelas, processos globais ligados aos empreendimentos industriais, agroindustriais e hidroindustriais se inscrevem nas paisagens. Há também dispositivos de controle e repressão estatal que terminam por posicionar a atividade de pesca de guaiamum do patamar da informalidade e desvalorização para o da ilegalidade. Por outro lado, as conexões dos gaiamunzeiros, seja com as articulações do Movimento dos Pescadores e Pescadoras Artesanais, seja com a condição de beneficiários de uma reserva extrativista ou de uma política de regularização dos territórios quilombolas, têm o potencial de dar visibilidade a práticas cotidianas de permanência na atividade de pesca e de existência histórica em seus 
territórios. Curiosamente, é a defesa de uma atividade de predação humana, a pesca de guaiamum, o que dá a chance aos guaiamuns de seguirem existindo, pois a defesa dessa atividade se confunde com a defesa da própria paisagem habitada por guaiamuns e pescadores.

O Movimento dos Pescadores e Pescadoras Artesanais tem produzido, nas suas reuniões e encontros (alguns dos quais pudemos acompanhar), debates inovadores sobre pesca, direitos, ecologia e territórios. Infelizmente, suas lutas e articulações têm encontrado pouca reverberação em debates públicos mais amplos. Os pescadores artesanais da Bahia, por exemplo, têm formulado uma narrativa, repetida em seus encontros e reuniões, se referindo à ideia de que a zona estuarina, a mare ${ }^{14}$, cuida dos pescadores, e que também precisa ser cuidada, utilizando nesse discurso a expressão Mãe Maré. Entendemos a Mãe Maré como uma referência à condição histórica dos manguezais enquanto área ecologicamente produtiva, de livre acesso, que provê segurança alimentar e trabalho à população atravessada pela condição histórica de pobreza, que encontra na pesca um espaço intersticial de autonomia.

As trajetórias de vida tanto de Jorge quanto de Marcos, assim como de outros pescadores de guaiamuns que acompanhamos, passam por fases longas de trabalho na maré e breves períodos de trabalho fichado nas empresas, em empregos como trabalhador braçal ou vigilante. Certa vez, em uma reunião do Conselho da Resex Acaú-Goiana, um pescador se referiu a essa relação entre a maré, a segurança alimentar e o desemprego com a seguinte frase: "A maré não diz 'não há vagas". $\mathrm{O}$ aumento da quantidade de pescadores nos manguezais e possíveis impactos de sobrepesca são atribuídos por nossos interlocutores, invariavelmente, a fases de aumento geral do desemprego, que trazem para a atividade novos e antigos praticantes da pesca.

A narrativa da Mãe Maré se conecta à ideia de uma paisagem estuarina produtiva e produzida pelas relações vivas do manguezal. Ser filho da Mãe Maré é colher os frutos de tais relações, cuidar e ser cuidado, e fazer parte delas pelo engajamento ativo nas atividades de pesca. Cuidar adequadamente da Mãe Maré é um debate em família, entre aqueles que vivem em seus fluxos e relações. Diz respeito à ética do pescador para com a maré. Entretanto, esse debate entre os pescadores se coloca em segundo plano quando a Mãe Maré é ameaçada pela destruição dos manguezais pelos mesmos tipos de agentes que procuram excluí-los das suas atividades.

No estuário do Rio Goiana, há canaviais, indústrias, fazendas de camarão, especulação imobiliária e poluição urbana; em São Francisco do Conde, há os impactos da extração e refino de petróleo, conflitos de terra, especulação imobiliária e poluição urbana, além de conflitos com a prefeitura. Por mais que alguns pescadores sejam considerados maus filhos da Mãe Maré, o que ameaça seu futuro se encontra para além do universo da pesca artesanal.

No momento em que escrevemos este artigo, a principal pauta do Movimento dos Pescadores e Pescadoras Artesanais é obter a votação de um projeto de lei de iniciativa popular que mobiliza uma outra categoria formulada pelos pescadores, a de territórios pesqueiros. $\mathrm{O}$ reconhecimento legal desses territórios ${ }^{15}$ inclui pos-
14 "Ir para a maré" é um termo usado entre os pescadores do Nordeste brasileiro como sinônimo de "ir pescar". Vale lembrar que é o fluxo das marés, ligado ao ciclo lunar, o principal responsável pelos processos de produtividade do mangue, assim como baliza a temporalidade do trabalho dos pescadores e o ciclo de vida de organismos como os guaiamuns.

15 A campanha dos pescadores em prol da regularização dos territórios pesqueiros pode se acessada pelo site http:// www.peloterritoriopesqueiro. blogspot.com. Acesso em: 28 abr. 2019. 
sibilidades diversas de reconhecimento da primazia da manutenção de paisagem biodiversas e aptas a atividade de pesca, sejam elas áreas de exclusivo usufruto dos pescadores ou de uso múltiplo, áreas públicas, privadas ou comunitárias, com a ressalva de que não sejam afetadas pelos processos de destruição, contaminação e interdição de acesso.

Territórios pesqueiros implicam a reivindicação de manutenção das condições socioambientais de existência da pesca artesanal. Assim, lutar por assegurar territórios pesqueiros é lutar ao mesmo tempo pelos direitos dos pescadores e pelos direitos da Mãe Maré, necessária para a manutenção dos modos de existência dos pescados, dos pescadores e das "vagas" de trabalho para quem sabe do ofício da pesca. A relação entre territórios pesqueiros (uma categoria de reivindicação para o Estado) e Mãe Maré (uma categoria significativa no debate político entre os pescadores) parece indicar uma interessante gramática das traduções cosmopolíticas (De la Cadena, 2015).

Quanto ao lugar do guaiamum e dos gaiamunzeiros nesses debates, sugerimos neste artigo uma ecologia política do guaiamum permeada de diversas situações que remetem a uma ideia de limite: a vida dos guaiamuns num ambiente de transição entre o mangue e áreas adjacentes, entre a terra e a água, e vazando os limites de áreas protegidas; a vida dos pescadores nos limites da economia informal e da visibilidade política, tendo o mangue como referência e segurança; a situação-limite das condições futuras de existência dos manguezais e dos modos de existência dos guaiamuns e dos seus pescadores; e por fim, os limites do Estado em lidar com a produção de uma política que agregue a diversidade dos modos de existência com criatividade na política ambiental.

A articulação dessas situações-limite sugerem que há um panorama de fricção nas paisagens da pesca do guaiamum: de um lado, processos de precarização onde se conformam a vida e a morte e se confundem o global e o local; de outro, a perspectiva estatal de gestão territorial e ambiental baseada no disciplinamento e no traçado de polígonos, frágil perante os interesses privados; e, por fim, a natureza fluida, intersticial e persistente das atividades de pesca artesanal. As histórias aqui narradas sobre a vida e a morte dos guaiamuns sugerem a urgência de se entenderem os fluxos de vida, as lutas políticas e a produção criativa de conhecimentos dos pescadores em novas estratégias de assegurar ressurgências de bem-viver de coletivos multiespécies que conformam os ambientes litorâneos em processo de precarização. 


\section{Referências}

ALVES, André; SAMAIN, Ettiene. Os argonautas do mangue precedido de Balinese character (re)visitado. Campinas: Editora Unicamp; São Paulo: Imprensa Oficial do Estado de São Paulo, 2004. p.

ANDRADE, Maiza Ferreira de; MORAES, Luiz Roberto Santos. Contaminação por chumbo em Santo Amaro desafia décadas de pesquisas e a morosidade do poder público. Ambiente e Sociedade, v. 16, n. 2, p. 63-80, 2013.

BARICKMAN, Bert Jude. Até a véspera: o trabalho escravo e a produção de açúcar nos engenhos do Recôncavo Baiano (1850-1881). Afro-Ásia, n. 21-22, p. 177-238, 19981999.

BURGGREN, Warren; MCMAHON, Brian. Biology of the land crabs. Cambridge: Cambridge University Press, 1988.

CARNEIRO DA CUNHA, Manuela; ALMEIDA, Mauro. 2000. Indigenous people, traditional people and conservation in the Amazon. Daedalus 129 (2), pp. 315-338.

CARDOSO, Thiago Mota. The multispecies life of feral dendezeiros: ethnography in motion. Engagement (American Anthropological Society), 2016. Disponível em: http:// www.aesengagement.wordpress.com/2016/02/02. Acesso em: 15 mar. 2019.

CARDOSO, Thiago Mota. Paisagens em transe: ecologia da vida e cosmopolítica Pataxó no Monte Pascoal. Brasília: IEB; Mil Folhas, 2018.

CARNEIRO DA CUNHA, Manuela; ALMEIDA, Mauro. 2000. Indigenous people, traditional people and conservation in the Amazon. Daedalus, v. 129, n. 2, p. 315-338, 2013.

DE LA CADENA, Marisol. 2015. Earth beings: ecologies of practice along Andean worlds. Durham: Duke University Press, 2015.

ESCOBAR, Arturo. Territorios de diferencia: la ontología política de los "derechos al territorio". Desenvolvimento e Meio Ambiente, v. 35, p. 89-100, 2015.

FIRMO, Angélica; TOGNELLO, Mônica; SILVA, Saulo; BARBOZA, Rayner; ALVES, Rômulo. Capture and commercialization of blue land crabs (guaiamum) Cardisoma guanhumi along the coast of Bahia state, Brazil: an ethnoecological approach. Journal of Ethnobiology and Ethnomedicine, v. 8, n. 12, p. 63-80, 2012.

GALLI, Orlando B. S. Texto-base para elaboração do Plano de Recuperação do caranguejo guaiamum (Cardisoma guanhumi Latreille, 1825). mimeo. 2016.

GEOGRAFAR. Comunidade negra rural quilombola Porto de Dom João: Relatório Preliminar, 2015.

GIBSON, James. The ecological approach to visual perception. Boston: Houghton Mifflin, 1979.

HILL, K. 2001. Species Inventory: Smithsonian Marine Station of Ford Pierce. 2001. Disponível em: http://www.sms.si.edu/irlspec/Cardis_guanhu.htm. Acesso em: 10 mar. 2019.

INGOLD, Tim. The perception of the environment. London: Routledge, 2000.

INGOLD, Tim. 2010. Da transmissão de representações à educação da atenção. Educação, v. 33, n. 1, p. 19-25, 2010.

INGOLD, Tim. 2016. Chega de etnografia! A educação da atenção como propósito da antropologia. Educação, v. 39, n. 3, p. 404-411, 2016.

LATOUR, Bruno. 1994. Jamais fomos modernos. São Paulo: Editora 34, 1994. 
Pedro Castelo Branco Silveira e Rafael Palermo Buti

LIMA, André; CAPOBIANCO, João Paulo. Mata Atlântica: avanços legais e institucionais para sua conservação. Documentos ISA, n. 4. São Paulo, Instituto Socioambiental, n. 4, 1997.

LITTLE, Paul. 2002. Territórios Sociais e Povos Tradicionais no Brasil: por uma antropologia da territorialidade. Brasília: DAN/Série Antropologia, n. 322, UnB, 2002. (Série Antropologia, n. 322).

OLIVEIRA NETO, J. F.; BATISTA, E.; METRI, R.; METRI, C. B. 2014. Local distribution and abundance of Cardisoma guanhumi in Southern Brazil. Brazilian Journal of Biology, $\mathrm{V}$. 74, n. 1, p. 1-7, 2014.

PINTO, Naiane Jesus. Experiência e memória: uma etnografia da experiência de migração forçada em Dom João em São Francisco do Conde-BA, no ano de 1982. 2016. 61 f. Trabalho de Conclusão de Curso (Bacharelado em Humanidades) - Instituto de Humanidades e Letras, Universidade da Integração Internacional da Lusofonia Afro-Brasileira, São Francisco do Conde, 2016.

ROBBINS, Paul. 2004. Political ecology: a critical introduction. New Jersey: Blackwell Publishing, 2004.

SAMPLE, Shannon; ALBRECHT, Marc. 2016. Determination of the burrow shapes of Cardisoma guanhumi on Vieques, Puerto Rico. Journal of Coastal Life Medicine, v. 4, n. 2, p. 94-97, 2016.

SANSONE, Livio. 2007. Contraponto baiano do açúcar e do petróleo: São Francisco do Conde, Bahia - 50 anos depois. In: PEREIRA, Claudio Luiz; SANSONE, Livio. Projeto Unesco no Brasil: textos críticos. Salvador: EdUFBA, 2007. p. 194-218.

SILVEIRA, Pedro. C. B.; PEDROSA, Beatriz M.; MELO, Luciana; ROSAS, Júlia C.; SANTOS, Luclécia; OLIVEIRA FILHO, Ivson. 2010. Reservas extrativistas e pesca artesanal - etnografia do campo socioambiental em Pernambuco: Relatório de pesquisa. Recife: Fundaj/Facepe, 2010.

SILVEIRA, PEDRO C. B.; PEDROSA, BEATRIZ M.; MELO, Luciana; OLIVEIRA FILHO, I. R. 2013. Estuário, paisagem-fluxo de pescadores artesanais. Iluminuras, v. 14, p. 304-323. 2013.

SOUTO, Francisco J. B. 2008. A ciência que veio da lama: etnoecologia em área de manguezal. Série Estudos e Debates, n. 5, Recife: Nupeea/SBEE, 2008. (Série Estudos e Debates, n. 5).

TSING, Anna. 2004. Friction: an ethnography of global connection. New Jersey: Princeton University Press, 2004.

TSING, Anna. 2012. Friction. In: RITZER, George. The Wiley-Blackwell encyclopedia of globalization. New Jersey: Wiley-Blackwell, 2012.

TSING, Anna. 2015a. Margens indomáveis: cogumelos como espécies companheiras. Ilha, v. 17, n. 1, p. 63-80, 2015a.

TSING, Anna. 2015b. The mushroom at the end of the world: on the possibility of life on capitalist ruins. New Jersey: Princeton University Press, 2015b.

TSING, Anna. 2013. More than human sociality: a call for critical description. In: HASTRUP, Kirsten (Org.). Anthropology and nature. London: Routledge, 2013.

TSING, Anna. 2019. Viver nas ruínas: paisagens multiespécies no Antropoceno. Brasília: Mil Folhas; IEB, 2019.

TSING, Anna; SWANSON, Heather; GAN, Elaine; BUBANDT, Nils. 2017. Arts of living on a damaged planet: ghosts and monsters of the Anthropocene. Minnesota: University of 
Pedro Castelo Branco Silveira e Rafael Palermo Buti

Minnesota Press, 2017.

VAN DOOREN, Thom; KIRKSEN, Eben; MÜNSTER, Ursula. 2016. Multispecies studies: cultivating arts of attentiveness. Environmental Humanities, v. 8, n. 1, p. 1-23, 2013. Disponível em: https://read.dukeupress.edu/environmental-humanities/article/8/1/1/61679/ Multispecies-StudiesCultivating-Arts-of. Acesso em: 10 mar. 2019.

VIVEIROS DE CASTRO, Eduardo. 2002. Imagens da natureza e da sociedade. In: A inconstância da alma selvagem e outros ensaios. São Paulo: Cosac \& Naify, 2002.

WATKINS, Case. African Oil Palms, Colonial Socioecological Transformation and the Making of an Afro-Brazilian Landscape in Bahia, Brazil. Environment and History, v. 21, n. 1, p. 13-42, 2015.

WEIS, Judith. Walking sideways: the remarkable world of crabs. New York: Cornell University Press, 2012. 